\title{
Linking ETM physics, zooplankton prey, and fish early-life histories to striped bass Morone saxatilis and white perch $M$. americana recruitment
}

\author{
E. W. North ${ }^{1,2, *}$, E. D. Houde ${ }^{1}$ \\ ${ }^{1}$ University of Maryland Center for Environmental Science, Chesapeake Biological Laboratory, PO Box 38, Solomons, \\ Maryland 20688, USA \\ ${ }^{2}$ Present address: University of Maryland Center for Environmental Science, Horn Point Laboratory, PO Box 775, \\ Cambridge, Maryland 21613, USA
}

\begin{abstract}
Transport to and retention of early-life history stages within the estuarine turbidity maximum (ETM) region may be an important component of recruitment success of the anadromous striped bass Morone saxatilis and the white perch $M$. americana. This hypothesis was evaluated with spatially resolved surveys of the physical and biological characteristics of the upper Chesapeake Bay estuary during 5 cruises, 3 in May 1998 and 2 in May 1999. Gradients in depth-specific patterns of larval abundance and zooplankton prey were evaluated with respect to salinity, temperature and total suspended solids (TSS). Although physical conditions in the upper estuary differed between cruises and years, the spatial patterns in distribution of larvae and potential prey were consistent and tracked changes in salt front and ETM locations. A statistical analysis suggested that location relative to the ETM explained a significant amount of variability in concentrations of eggs, yolk-sac larvae, and larval prey, and that prey concentrations accounted for a significant amount of variability in concentrations of feeding larvae. Transport to the ETM region probably occurs during the egg (striped bass) and yolk-sac larva (white perch) stages and results in retention of early-stage feeding larvae in a zone of high prey concentrations. Physical conditions in the ETM region differed markedly between a low freshwater-flow year (1999) and a high flow year (1998), and abundances of striped bass and white perch post-yolk-sac larvae were significantly lower in 1999. Recruitment variability was poorly correlated with spawning stock biomass, but spawner-recruitment models that incorporated spring freshwater discharge explained an additional 41\% (striped bass) and 30\% (white perch) of the variability in recruitment. Annual changes in freshwater flow could control larval survival and recruitment by modifying the physical and biological characteristics of the ETM region.
\end{abstract}

KEY WORDS: Physical-biological interactions · Estuarine turbidity maximum • Chesapeake Bay · Fish recruitment $\cdot$ Zooplankton

Resale or republication not permitted without written consent of the publisher

\section{INTRODUCTION}

The idea that year-to-year changes in environmental conditions may be an underlying cause of recruitment variability is a fundamental paradigm in fisheries science (Sissenwine 1984). Interactions between physics and biology during early life could control survival and recruitment by (1) affecting the timing and extent of prey availability (Hjort 1914, Cushing 1975), (2) influ- encing growth rates and trophic interactions that shape temporal and spatial co-occurrence with predators (Bailey \& Houde 1989, Houde 1989), (3) regulating larval feeding success via turbulence-induced encounter rates (Rothschild \& Osborn 1988), and (4) controlling dispersal to, or retention within, nursery areas (Iles \& Sinclair 1982).

Estuarine turbidity maxima (ETMs), which are characterized by elevated turbidity and suspended sedi- 
ment concentrations compared to those up- and downestuary, are found in coastal-plain estuaries throughout the world (Schubel 1968). The ETM region is an important nursery area for larval fishes in the St. Lawrence River estuary (Dodson et al. 1989, Dauvin \& Dodson 1990, Sirois \& Dodson 2000) and potentially in the San Francisco Bay/Delta (Jassby et al. 1995). Fish eggs and larvae retained within the ETM region may be in (1) a zone of increased zooplankton biomass and production (Simenstad et al. 1994, Boynton et al. 1997, Kimmerer et al. 1998, Roman et al. 2001), (2) a predation refuge due to high turbidity (Chesney 1989), and (3) optimal salinity or temperature conditions (Strathmann 1982). In addition, retention within the ETM could prevent eggs and larvae from entering osmotically stressful, high-salinity waters (Winger \& Lasier 1994).

Earlier research in Chesapeake Bay suggested that a critical habitat for estuarine fish larvae occurred in the transition zone between fresh- and salt-waters (Massmann 1963, Dovel 1971). Recent research identifies the ETM as a physical feature within the transition zone that forms the nursery habitat. Elevated abundance of striped bass Morone saxatilis larvae, white perch M. americana larvae, and their potential prey were reported in and near the Chesapeake Bay ETM (Boynton et al. 1997, North \& Houde 2001, Roman et al. 2001). Boynton et al. (1997) suggested that the ETM region could be an important nursery area for larval fishes where biological conditions structured by the physics of the region could enhance recruitment potential. North \& Houde (2001) proposed that variations in early-life-stage retention, larval survival and juvenile recruitment may be related to annual differences in freshwater flow that alter the physical and biological characteristics of the ETM region.

Although both striped bass and white perch are anadromous species that spawn during spring (peaking in April and May) in the headwaters of Chesapeake Bay and its tributaries (Mansueti 1964, Dovel 1971), their life-history strategies differ. Striped bass spawn buoyant eggs in tidal freshwaters that are upestuary of the salt front (Dovel 1971, Secor \& Houde 1995), whereas white perch spawn demersal eggs that adhere to the substrate in tidal fresh and brackish waters (Mansueti 1961, Setzler-Hamilton 1991). The slightly heavy striped bass eggs (specific gravity = 1.0005 to 1.0066: Albrecht 1964, Rulifson \& Tull 1999) are suspended by currents $>0.3 \mathrm{~m} \mathrm{~s}^{-1}$ (Albrecht 1964). Although both striped bass and white perch eggs hatch in about $2 \mathrm{~d}$ (depending upon temperature), striped bass yolk-sac larvae hatch at a length of 2.9 to $3.7 \mathrm{~mm}$ (Mansueti 1958), while white perch yolk-sac larvae hatch at a length of 1.7 to $3.0 \mathrm{~mm}$ (Mansueti 1964). White perch larvae absorb the yolk sac, develop a swim bladder, and begin feeding on rotifers, copepod nauplii and small copepodites 3 to $5 \mathrm{~d}$ posthatch at a length of $\sim 3.8 \mathrm{~mm}$ (Mansueti 1964, Setzler-Hamilton et al. 1982). Their diets shift to larger copepodites, the copepod Eurytemora affinis and the cladoceran Bosmina longirostris with increasing development (Beaven \& Mihursky 1980, Setzler-Hamilton et al. 1982, Limburg et al. 1997). In contrast, striped bass larvae do not develop a swim bladder and absorb their yolk sac until they are $>5 \mathrm{~d}$ old and $>5 \mathrm{~mm}$ in length (Mansueti 1958, 1964, Doroshev 1970). Striped bass larvae begin feeding on rotifers, copepodites, and $B$. longirostris before shifting toward adult copepods (including E. affinis) and larger cladocerans as they grow (Setzler-Hamilton et al. 1982). Both congeners use the upper Chesapeake Bay as a juvenile nursery area.

Seasonal and annual changes in ETM properties may have consequences for larval survival and recruitment because the location and extent of the ETM nursery area and the circulation patterns that influence early-stage retention are implicitly linked to the variable physics of the region. Although the ETM is a wellestablished feature of the upper Chesapeake Bay, its location and intensity vary among hours, days, seasons and years depending upon tidal excursion, wind forcing and the amount of freshwater flow (Boynton et al. 1997, North \& Houde 2001, Sanford et al. 2001). The ETM ranges from 10 to $30 \mathrm{~km}$ in extent and is generally associated with the tip of the 1 psu isohaline, but can be displaced from it by as much as $10 \mathrm{~km}$ due to tidal excursion (Boynton et al. 1997, Sanford et al. 2001).

In an earlier study, using a descriptive analysis of physical conditions and early-life stage distributions, we (1) demonstrated that physical characteristics of the ETM region were influenced by wind and freshwater flow, (2) concluded that the ETM region is an important nursery area for striped bass and white perch early-life stages, and (3) presented a hypothesis that proposed relationships between physical conditions and variations in larval fish abundance, potential survival and recruitment (North \& Houde 2001). Herein, we statistically evaluate the spatial and temporal patterns in depth- and stage-specific distributions of striped bass and white perch earlylife stages in relation to the depth-specific distributions of their potential prey (copepod Eurytemora affinis and cladocera Bosmina longirostris) and to the physical characteristics of the ETM region. The results, combined with freshwater discharge data and young-of-the-year and adult fish abundance data, are used to quantitatively link environmental variability to juvenile recruitment by incorporating freshwater flow into striped bass and white perch spawner-recruit models. 


\section{MATERIALS AND METHODS}

In the upper Chesapeake Bay (Fig. 1), 5 cruises were conducted during the spawning seasons of striped bass and white perch on the $15.9 \mathrm{~m} \mathrm{RV}$ 'Orion': 3 cruises were in May 1998 (2 to 5, 11 to 14 and 19 to 22 May, referred to as 98-1, 98-2, 98-3, respectively) and 2 were in May 1999 (4 to 6 and 17 to 19 May, referred to as 99-1 and 99-2). On each cruise, the ETM was located with an initial axial CTD survey. A gradient-mapping survey was conducted 1 to $2 \mathrm{~d}$ after the axial survey. During the gradient-mapping survey, plankton-net tows were used to map the depth-specific distributions of ichthyoplankton and zooplankton above, within and below the ETM region in the channel of the Bay.

The location of the ETM and landward margin of salt intrusion (defined as the intersection of the 1 psu isohaline with the bottom) were determined from an axial CTD survey on each cruise using a Seabird CTD equipped with a SeaTech $5 \mathrm{~cm}$ pathlength transmissometer to measure salinity, temperature, and turbidity. Water samples $(100 \mathrm{ml})$ were collected with a pump attached to the CTD frame to calibrate turbidity (nephelometer turbidity units) measurements with total suspended solids (TSS) concentrations. Based on results of the axial survey, 6 gradient-mapping stations were designated: 1 within the ETM, and 2 up-estuary and 3 down-estuary from the ETM station at intervals equal to one-half of the tidal excursion (first cruise) or two-thirds of the tidal excursion (remaining cruises) at the ETM location (Fig. 1).

Sampling at the gradient-mapping stations was conducted in an up-estuary to down-estuary sequence at night and was completed in 7 to $8 \mathrm{~h}$. A CTD cast was made at each station, after which ichthyoplankton and zooplankton were collected in 2 min depth-stratified tows of a Tucker trawl in 2 or 3 depth intervals, depending on water depth. The $1 \mathrm{~m}^{2}$ opening-closing trawl had $280 \mu \mathrm{m}$-mesh nets, a flowmeter, and a temperature-depth recorder. Mean volume filtered of individual tows was $114.7 \mathrm{~m}^{3}( \pm 2.4 \mathrm{SE})$. Most Tucker-trawl tows were made in surface ( 0 to $3.5 \mathrm{~m}$ ), mid-depth ( 3.5 to $7 \mathrm{~m}$ ), and near-bottom ( 7 to $11 \mathrm{~m}$ ) intervals. Ichthyoplankton samples were preserved in ethanol and taken to the laboratory for subsequent enumeration and identification. Striped bass and white perch post-yolk-sac larvae $<10 \mathrm{~mm}$ in total length were identified using morphological criteria (Waldman et al. 1999) and then measured. Larvae $>10 \mathrm{~mm}$ were not analyzed because striped bass and white perch larvae $>10 \mathrm{~mm}$ are difficult to identify to species and were not effectively captured by the Tucker trawl.

After removal of ichthyoplankton, Tucker-trawl samples were prepared for zooplankton analysis by filtering them through a $1 \mathrm{~mm}$ sieve to remove large zoo- plankton. Then, the $<1 \mathrm{~mm}$ fraction was split (up to $1 / 64$ ) with a plankton splitter and diluted to $50-400 \mathrm{ml}$, depending upon the number of organisms in the sample. Counts of copepods and cladocerans from three $1 \mathrm{ml}$ aliquots were averaged and used to determine the concentration (no. $\mathrm{m}^{-3}$ ) of organisms $<1 \mathrm{~mm}$. Eurytemora affinis and Bosmina longirostris distributions were compared to larval fish distributions because they had been the most common food of larval striped bass and white perch (Beaven \& Mihursky 1980, Setzler-Hamilton et al. 1982, North 2001) and because they comprised $66 \%$ of the zooplankton in the $280 \mu \mathrm{m}$ net collections. Different sizes of fish larvae have different gape limitations, so E. affinis copepods were grouped into 2 size classes: copepodites and adult males (small) and adult females (large). Because some copepods and cladocerans may have been extruded from the $280 \mu \mathrm{m}$ meshes, concentration estimates reported here are indices of actual concentrations.

Data on freshwater discharge, water level, wind, and water temperature were used to identify large-scale environmental forcing that produced the physical conditions during the cruises. Since nearly all freshwater input to the upper Bay is from the Susquehanna River (Schubel \& Pritchard 1986), daily mean discharge data (US Geological Survey) for the Susquehanna River at the Conowingo Dam in Maryland (Fig. 1) was used to index freshwater input.

Results from cruises were mapped with contour plots of physical factors and ichthyoplankton and zooplankton concentrations (Golden Software, Surfer 7.0). The gridding method was kriging based on an isotropic

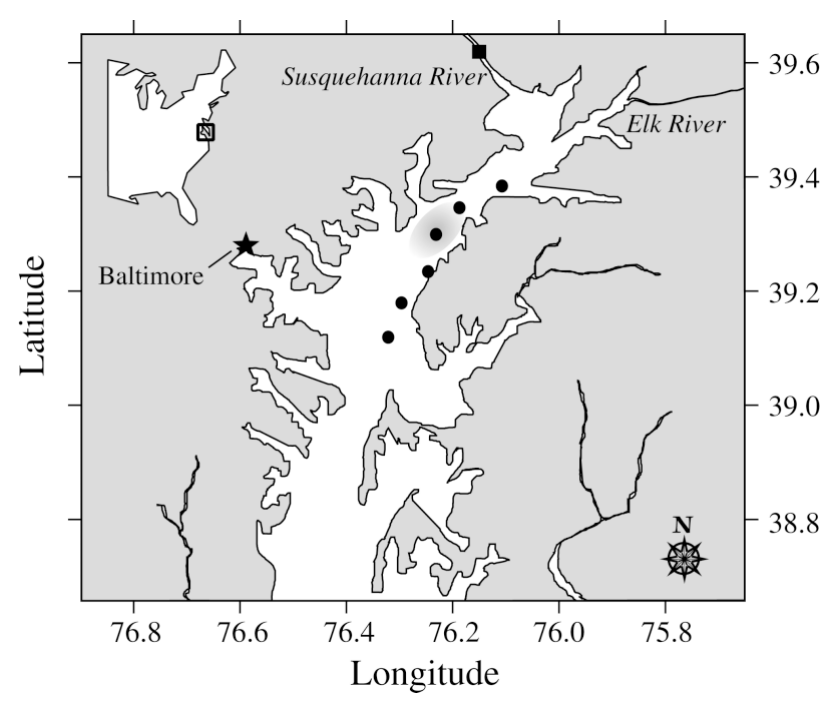

Fig. 1. Upper portion of Chesapeake Bay, USA. $(\bullet)$ Gradientmapping stations from 19 to 22 May 1998 research cruise; shaded area: ETM; (๘) Conowingo Dam, site of freshwater discharge measurements on Susquehanna River. Latitudes and longitudes are in decimal fractions. $\star$ : Baltimore City 
linear variogram model. Grid-line geometry was no less than half the average distance between measurements in the X (distance) and Y (depth) directions. In the contour plots, station locations were expressed as 'kilometers from river mouth', the distance from the mouth of the Susquehanna River (Fig. 1). The ETM region was defined as $\pm 10 \mathrm{~km}$ from maximum TSS concentrations. Mean abundances (after $\log _{\mathrm{e}}$-transformation) of white perch yolk-sac larvae, post-yolk-sac larvae and potential prey were tested for differences between years with an ANOVA (SAS 6.12, PROC MIXED) with cruise designated as a random effect.

To quantify spatial overlap between potential prey and fish early-life stages, overlap indices (Schoener 1970) were calculated for each cruise and then averaged to determine mean overlap for each year. Percent overlap was calculated as: percent overlap = $100\left[1-0.5\left(\sum\left|p_{i x, t}-p_{j x, t}\right|\right)\right]$, where $p_{i x, t}=C_{i X, t} / \sum c_{i}$, the proportion of the total concentrations of organism $i$ found at depth $x$ and time $t$, and $p_{j x, t}=c_{j x, t} / \sum c_{j}$, the proportion of the total concentrations of organism $j$ found at the same depth $x$ and time $t$. The Schoener index is proposed to be a simple yet relatively robust index of niche overlap (Abrams 1980, Linton et al. 1981, Crowder 1990). Although often calculated for proportions of resources used by 2 species (i.e. diets), the index here quantifies the simplest measure of potential competition or predation: spatial overlap. High overlap values imply greater spatial co-occurrence. Overlap indices were tested for significance using EcoSim software ${ }^{1}$ to calculate the Czechanowski index (identical to the Schoener index) and probability levels following the 'RA3' method described in Winemiller \& Pianka (1990) and Albrecht \& Gotelli (2001). Mean overlap indices (and standard errors) are reported for organisms with significant overlap $(\alpha=0.05)$ in all cruises in 1998 or in 1999.

Statistical analysis. Exploratory repeated-measures, multiple-regression analyses were conducted to determine if salinity, temperature, TSS, location within the estuary, or prey concentrations accounted for a significant amount of variability in the concentrations of larvae by size class (SAS 8.0 PROC MIXED with Kenward-Rogers degrees of freedom method). A repeated-measures design was used to model the covariance between samples at adjacent depths and correct for any lack of independence. An 'unstructured' covariance matrix was used to allow the covariance between depths to differ between stations. All models passed tests for normality (Shapiro-Wilks test)

\footnotetext{
${ }^{1}$ Gotelli NJ, Entsminger GL (2003) EcoSim: null models software for ecology, Version 7. Acquired Intelligence \& Kesey-Bear, Burlington, VT, available at http://homepages. together.net/ gentsmin/ecosim.htm
}

and homogeneity of variance (Pearson correlation tests of Iresiduall versus predicted values). In addition, all explanatory variables passed multicollinearity tests (tolerance $>0.11$, condition index $<7.00$, SAS 6.12 PROC REG, PROC PRINCOMP). The regression analyses were limited to data from 1998 because variances in 1999 data were heterogeneous due to the many zero observations in that year.

The multiple regression analyses were conducted on $\log _{\mathrm{e}}$-transformed larval and prey concentrations, with cruise designated as a random effect. Metrics for physical factors were the averaged CTD measurements within net tow-depth intervals. After a descriptive analysis, salinity and TSS were coded as dichotomous variables to represent fresh or saline waters ( 0 when salinity was $<1 \mathrm{psu}$, otherwise 1) and low or high turbidities ( 0 when TSS was $<47 \mathrm{mg} \mathrm{l}^{-1}$, otherwise 1 ). In addition, tow depth, distance along the axis of the upper Bay, and distance from the ETM (ETM center $=0$ ) were included in the statistical models as fixed effects. Prey concentrations were added to the models with respect to larval developmental stage (feeding or not feeding) and larval size. The model for white perch larvae $<5$ mm included Eurytemora affinis copepodites and adult males as well as Bosmina longirostris. The models for larvae $>5 \mathrm{~mm}$ included all E. affinis copepods (adult females summed with copepodite and male concentrations) and B. longirostris.

For comparison with the larval fish models, repeated-measures, multiple regression analyses also were conducted on Eurytemora affinis copepodites and adult males, E. affinis adult females, and Bosmina longirostris. Due to lack of model fit, distance factors were recoded in the model for $B$. longirostris: axial distance (distance from the Susquehanna River mouth) was coded as 'above ETM' (1 = up-estuary and within the ETM center, 0 = down-estuary of the ETM center) and the interaction between this variable and tow depth ('above ETM' $\times$ depth) was added to the model.

Coefficients of determination $\left(\mathrm{R}^{2}\right)$ from repeatedmeasures, regression models with fixed and random effects are unreliable so are not reported. Instead, $F$ values are included in Table 2 to indicate the relative amount of variance accounted for by fixed effects. The random effect 'cruise' was not significant in any of the models, so was excluded from Table 2.

Stock-recruitment models. To explore possible relationships between river flow and juvenile recruitment, a stock-recruit model incorporating spring freshwater discharge was fit to upper Chesapeake Bay striped bass and white perch recruitment and spawning stock abundance (SSA) indices. A Pearson correlation analysis was conducted prior to model fit to determine whether young-of-the-year (YOY) and SSA indices were correlated with freshwater discharge. YOY in- 
dices were square-root-transformed, and SSA indices were $\log _{\mathrm{e}}$-transformed to meet normality assumptions of correlation significance tests. Spring Susquehanna River flow rates for each year were means of daily discharge data from March through May. The striped bass and white perch YOY abundance indices (1987 to 1999) for the upper Bay were derived from the Striped Bass Seine Survey, data provided by the Maryland Department of Natural Resources (see www.dnr.state. md.us/fisheries/juvindex/index.html). Juvenile abundance indices (no. haul ${ }^{-1}$ ) were the mean number of fishes caught in replicate hauls of a beach seine set at 7 stations that were sampled 3 times between July and September each year. The 7 stations were located in the upper Chesapeake Bay and Elk River. Goodyear (1985) reported a significant relationship $\left(R^{2}=0.83\right)$ between juvenile indices from the Striped Bass Seine Survey and future striped bass landings in a $21 \mathrm{yr}$ timeseries.

Spawning stock abundance indices (1987 to 1999) of striped bass and white perch were calculated as catchper-unit-effort (CPUE), using data from the 'striped bass spawning stock survey' conducted by the Maryland Department of Natural Resources (Hornick et al. 1999). These indices were derived from catches in multi-mesh panels of experimental drift gillnets that were fished in the upper Chesapeake Bay $6 \mathrm{~d}$ per wk from late March or early April until catches dropped to zero, usually in late May. Striped bass were measured and categorized as male or female during the entire time series. Although white perch were not measured and sexed consistently during all years, most fish were female $(\sim 80 \%)$ in years when all fish were measured and sexed $(1996,1997)$ (North 2001). Spawning stock abundance indices were calculated as catch-per-uniteffort (number $\mathrm{m}^{-2} \mathrm{~d}^{-1}$ ) by summing the total catch of white perch or $>500 \mathrm{~mm}$ female striped bass for the entire spawning season and dividing by total effort. The Maryland Department of Natural Resources defines $500 \mathrm{~mm}$ as the minimum length at maturity of striped bass females in spawning stock assessments (Hornick et al. 1999).

A Ricker stock-recruit model was fit to the striped bass and white perch YOY and SSA data: $R=a S \mathrm{e}^{-b S}$, where $R=$ number of recruits (number YOY haul ${ }^{-1}$ ) and $S=$ spawning stock abundance. The coefficients represent density-independent (a) and stock-dependent $(b)$ mortality, with $a=f \times \mathrm{e}^{-u_{0} t}$ and $b=u_{1} \times f \times t$, where $u_{0}=$ density-independent mortality, $u_{1}=$ stockdependent mortality, $f=$ fecundity constant, and $t=$ time. The Ricker model ensures zero recruitment when stock size is zero (Ricker 1975, Fogarty 1993a) and allows for low recruitment at high spawning stock sizes related to stock-dependent mortality (Hilborn \& Walters 1992).
A density-independent mortality term for freshwater discharge was added to the Ricker stock-recruit model (Hilborn \& Walters 1992): $R=a S \mathrm{e}^{-b S-c D}$, where $D=$ spring (March, April, May) Susquehanna River discharge $\left(100 \mathrm{~m}^{3} \mathrm{~s}^{-1}\right)$, and $c=$ discharge-related mortality. The linearized forms of the Ricker model, $\log _{\mathrm{e}}(R / S)=\log _{\mathrm{e}}(a)-b S$, and the model with discharge, $\log _{\mathrm{e}}(R / S)=\log _{\mathrm{e}}(a)-b S-c D$, were fit to obtain initial parameter estimates (SAS 6.12 PROC REG) for the nonlinear model fit in PROC NLIN. In general, the nonlinear models with additive normal errors provided better fits than models with multiplicative lognormal errors. All models passed tests for autocorrelation (SAS 6.12 PROC ARIMA) and Runs Tests (Draper \& Smith 1981). Adjusted $R^{2}$ values were calculated for the nonlinear models with PROC MODEL in SAS 6.12.

\section{RESULTS}

\section{Physics}

Freshwater flow to the upper Bay in spring differed between 1998 and 1999. In a $30 \mathrm{yr}$ time series, spring discharge (mean of March, April and May discharge) in 1998 was above average (75th percentile), while that for 1999 was below average (10th percentile). May 1999 was the driest May in the 30 yr record.

Discharge in May 1998 was distinguished by a large peak during the second research cruise (Fig. 2). The peak in flow was preceded by strong winds from the north that caused the water level to decrease in the upper Bay (North \& Houde 2001). After the wind-forcing and high freshwater-flow events, discharge declined steadily prior to the third research cruise. The most

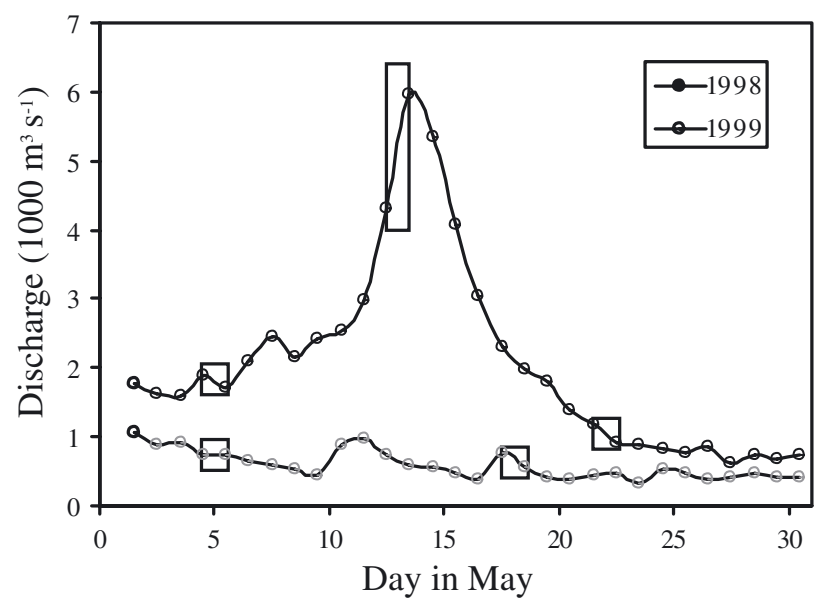

Fig. 2. Daily Susquehanna River discharge at Conowingo Dam in May 1998 and 1999. Boxes indicate dates of gradientmapping cruises 
notable feature of environmental conditions in May 1999 was the uniformly low discharge rate (Fig. 2).

Salinity and TSS profiles from the gradient-mapping surveys illustrate the differences in environmental conditions between cruises and years. During the first cruise in 1998 (Cruise 98-1) the salt front was located near Km 36 (Fig. 3a); 8 d later (Cruise 98-2), the pycnocline had intensified and the salt front had moved upestuary in response to the wind event followed by the peak in discharge (Fig. 3b). Salinity in the lower layer increased substantially, as indicated by the location of the intersection of the 5 psu isohaline with the bottom, which had shifted more than $15 \mathrm{~km}$ up-estuary between the first and second cruise in response to the northern wind event. By the third research cruise (98-3), after the peak in freshwater discharge, the salt front had moved down-estuary and stratification had weakened (Fig. 3c). During each survey in 1998, maximum TSS concentrations were near the foot of the salt front.

In 1999, TSS concentrations were generally lower than in 1998, while salinity was higher (Fig. 3d,e). Stratification near the salt front was less intense, and the intersections of the 1 psu isohalines with the bottom were about $15 \mathrm{~km}$ further up-estuary than in 1998. Peak TSS concentrations in 1999 were not as closely associated with the landward margin of salt intrusion (the intersection of the 1 psu isohaline with bottom) as those in 1998, suggesting that the ETM region was dis-
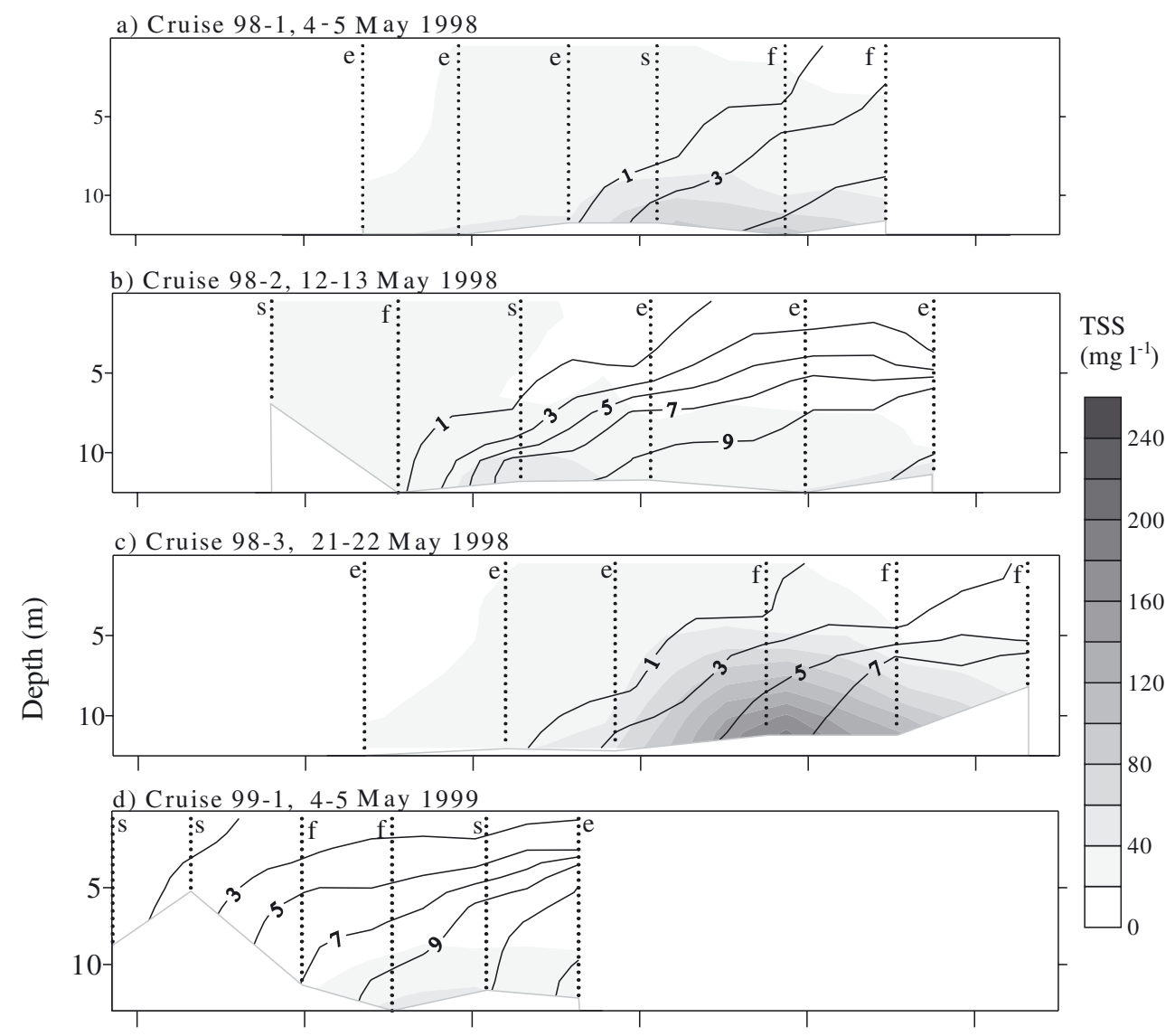

TSS $\left(\mathrm{mg} \mathrm{l}^{-1}\right)$

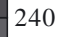

200

160

120

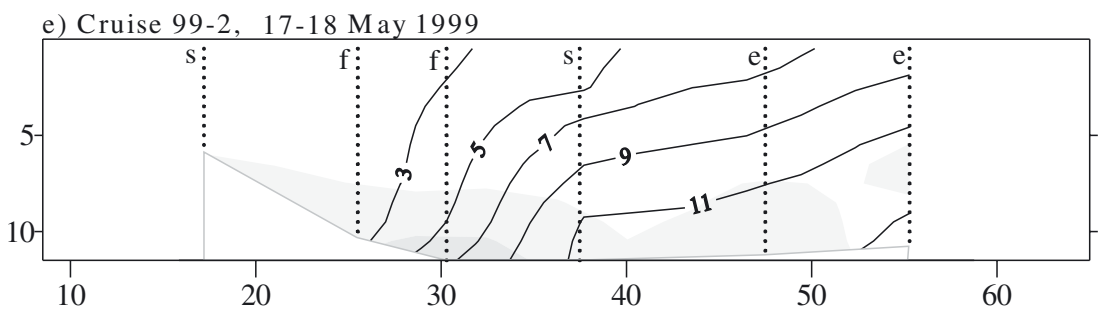

Kilometers from river mouth

Fig. 3. Contour shading of total suspended solids (TSS) and contour lines of salinity (psu) for gradient-mapping surveys in 1998 and 1999. Location of each CTD cast is marked by letter representing stage of the predicted tide (e: ebb; s: slack; f: flood) 
placed from the foot of the salt front in 1999. Although mean temperatures were $\sim 0.5$ to $1.0^{\circ} \mathrm{C}$ lower in 1999 than in 1998 , temperatures were above $12^{\circ} \mathrm{C}$ (the lethal limit for striped bass eggs [Setzler-Hamilton \& Hall 1991)] in salinities <11 psu during both years. The salinity structure during the 4 and 5 May 1999 cruise was more stratified than on 17 and 18 May, perhaps due to north winds just prior to the first cruise.

\section{Biology}

Most of the ichthyoplankton catch was composed of striped bass and white perch early-life stages (71\%), with the remainder being clupeid species-the alewife Alosa pseudoharengus, the blueback herring A. aestivalis, and the gizzard shad Dorosoma cepedianum. The total catches of white perch early life stages

a) Striped bass eggs

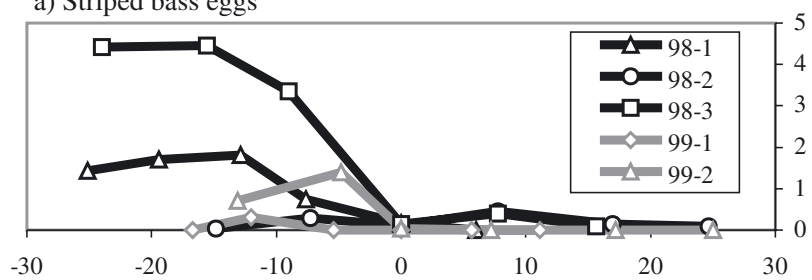

b) Striped bass yolk-sac larvae

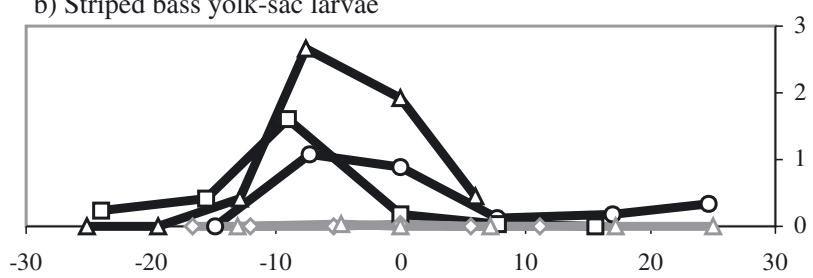

c) Striped bass larvae $5-8 \mathrm{~mm}$

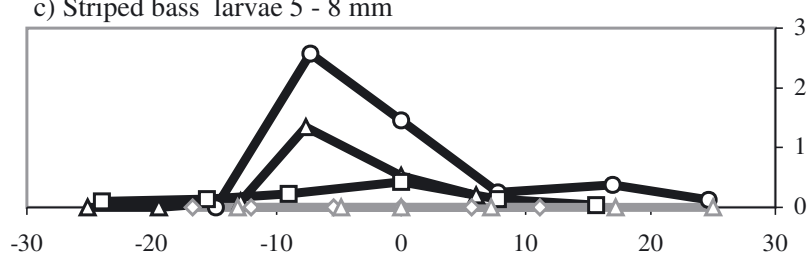

d) Striped bass larvae $8-10 \mathrm{~mm}$

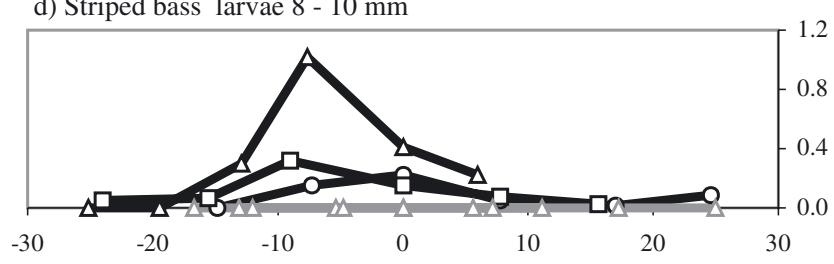

were $\sim 4$ times higher than those of striped bass, and the total catches of white perch post-yolk-sac larvae were 16 times higher. The abundances of striped bass and white perch yolk-sac and post-yolk-sac larvae were lower in 1999 than in 1998 (Fig. 4). There was no difference in mean abundance $\left(\log _{\mathrm{e}}\right.$ no. $\left.\mathrm{m}^{-2}\right)$ of white perch yolk-sac larvae between 1998 and 1999 (ANOVA, $F=2.31, \mathrm{p}=0.23, \mathrm{n}=30$ ) but the mean abundance of post-yolk-sac larvae was lower in 1999 (ANOVA, $F=15.56, \mathrm{p}=0.0005, \mathrm{n}=30$ ). Similar statistical analyses were not conducted for striped bass larvae because only 2 yolk-sac and no post-yolk-sac larvae were collected in gradient-mapping surveys in 1999. Striped bass eggs were present in 1999 (mean 0.60 eggs $\left.\mathrm{m}^{-3} \pm 0.34 \mathrm{SE}\right)$, but were fewer in number than in 1998 (mean 11.7 eggs $\mathrm{m}^{-3} \pm 6.5 \mathrm{SE}$ ).

Mean abundance of the cladoceran Bosmina longirostris was lower in 1999 (mean $=138.4 \pm 63.6 \mathrm{SE})$

e) White perch yolk-sac larvae

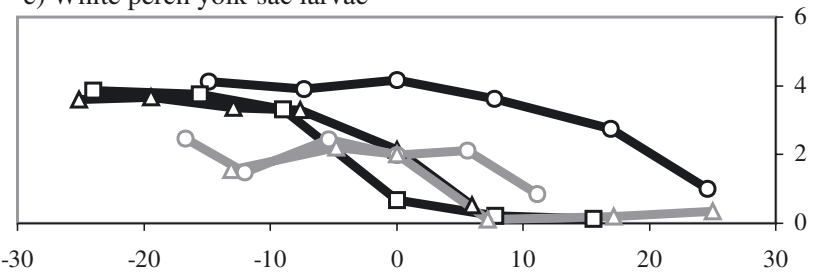

f) White perch larvae $<5 \mathrm{~mm}$

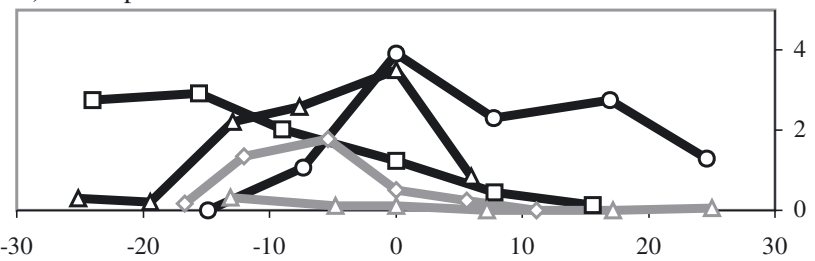

g) White perch larvae $5-8 \mathrm{~mm}$

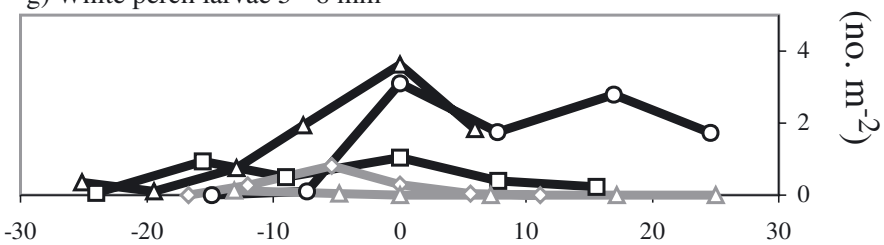

h) White perch larvae $8-10 \mathrm{~mm}$

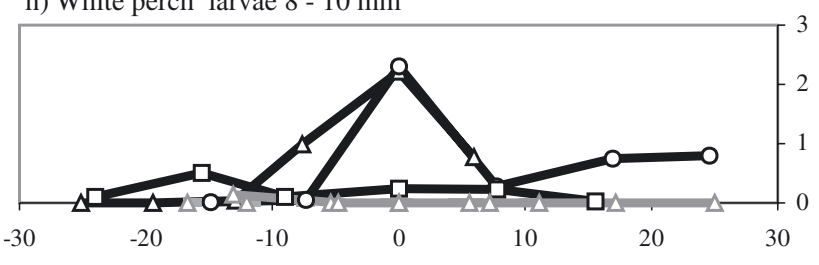

Kilometers from maximum TSS

Fig. 4. Morone saxatilis and M. americana. Striped bass and white perch abundance of each early-life stage versus distance from maximum total suspended solids (TSS) concentrations for each cruise in 1998 (98-1, 98-2, 98-3) and 1999 (99-1, 99-2). Negative numbers indicate distance up-estuary of maximum TSS 
than in $1998($ mean $=3870.7 \pm 1101.2 \mathrm{SE})($ ANOVA, $F=$ $39.38, \mathrm{p}<0.0001, \mathrm{n}=30$ ). Although this could indicate that $B$. longirostris abundance declined in the ETM region, this result is uncertain because sampling in 1999 did not span the same salinity gradient as that in 1998, i.e. sampling in 1999 was infrequent in salinities $<1$ psu (4 of 32 net tows), where $78 \%$ of $B$. longirostris were collected in 1998. There was no difference in mean abundance of Eurytemora affinis copepods (copepodites and adults) between 1998 (mean $=40988.5 \pm$ 11158.5 SE) and $1999($ mean $=36426.0 \pm 8466.3 \mathrm{SE})$ (ANOVA, $F=0.14, \mathrm{p}=0.71, \mathrm{n}=30$ ).

Although physical conditions differed between cruises and years, there were consistent patterns in the distribution of striped bass and white perch early-life stages and their zooplankton prey. For example, most striped bass eggs and white perch yolk-sac larvae (>69\%) were found in bottom and mid-depth waters (Table 1).
In addition, striped bass eggs and white perch yolk-sac larvae were most abundant up-estuary of maximum TSS concentrations (Fig. 4a,e). In multiple-regression models fit to 1998 data, axial distance (distance from the Susquehanna River mouth) was the only variable that described a significant amount of the variability in both striped bass egg and white perch yolk-sac larvae concentrations, indicating that abundances declined from up- to down-estuary (Table 2a,b).

Later stages of striped bass and white perch larvae also showed consistent patterns in their distribution in 1998. Most striped bass yolk-sac larvae (90\%), striped bass post-yolk-sac larvae (>83\%) and white perch post-yolk-sac larvae (>65\%) were found within $10 \mathrm{~km}$ of maximum TSS concentrations (Table 1, Fig. 4) and in bottom and mid-depth waters ( $>73 \%$ for all stages of both species, Table 1). Despite these similarities, significant overlap did not occur between striped bass

Table 1. Morone saxatilis and M. americana. Mean (SE) percentage of eggs, larvae (by size-class), and zooplankton prey collected during cruises in 1998 and 1999 in relation to physical factors or depth intervals. YSL: yolk-sac larvae. In 1999, only 2 of 34 net tows contained striped bass YSL and white perch post-YSL of 8 to $10 \mathrm{~mm}$, and no tows in 1999 contained striped bass post-YSL. No samples were collected from salinities <1 psu during the second cruise in 1999 (-). Zooplankton prey included the cladocera Bosmina longirostris, Eurytemora affinis copepodites plus males (cop.), E. affinis adult females, and all E. affinis copepods combined (all)

\begin{tabular}{|c|c|c|c|c|c|c|c|c|c|c|c|c|c|c|}
\hline \multirow[t]{2}{*}{ Location } & \multicolumn{5}{|c|}{$\longrightarrow$ Striped bass } & \multicolumn{5}{|c|}{ White perch } & \multicolumn{4}{|c|}{ _Zooplankton prey } \\
\hline & Eggs & YSL & \multicolumn{3}{|c|}{ 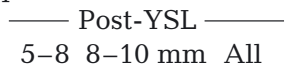 } & YSL & \multicolumn{4}{|c|}{ Post-YSL } & $\overline{\text { Cop. }}$ & $\begin{array}{l}\text { E. affinis } \\
\text { Female }\end{array}$ & $S-\bar{s}$ All & $\begin{array}{l}\text { B. longi- } \\
\text { rostris }\end{array}$ \\
\hline 1998 & & & & & & & & & & & & & & \\
\hline $\begin{array}{l}\text { Within } 10 \mathrm{~km} \\
\text { of max. TSS }\end{array}$ & $\begin{array}{c}\mathbf{3 2 . 4} \\
(20.3)\end{array}$ & $\begin{array}{c}\mathbf{9 0 . 1} \\
(3.8)\end{array}$ & $\begin{array}{c}\mathbf{9 2 . 6} \\
(3.9)\end{array}$ & $\begin{array}{c}83.5 \\
(2.2)\end{array}$ & $\begin{array}{c}\mathbf{9 0 . 8} \\
(3.2)\end{array}$ & $\begin{array}{c}\mathbf{3 9 . 8} \\
(11.7)\end{array}$ & $\begin{array}{c}\mathbf{6 5 . 0} \\
(18.0)\end{array}$ & $\begin{array}{c}\mathbf{7 6 . 4} \\
(10.3)\end{array}$ & $\begin{array}{c}\mathbf{7 8 . 1} \\
(13.8)\end{array}$ & $\begin{array}{c}\mathbf{6 6 . 9} \\
(16.7)\end{array}$ & $\begin{array}{c}\mathbf{7 0 . 5} \\
(16.0)\end{array}$ & $\begin{array}{c}\mathbf{7 9 . 7} \\
(11.6)\end{array}$ & $\begin{array}{c}\mathbf{7 2 . 0} \\
(15.3)\end{array}$ & $\begin{array}{c}\mathbf{4 2 . 3} \\
(10.2)\end{array}$ \\
\hline $\begin{array}{l}\text { In salinity } \\
<1 \mathrm{psu}\end{array}$ & $\begin{array}{c}\mathbf{7 5 . 3} \\
(21.8)\end{array}$ & $\begin{array}{c}\mathbf{5 1 . 4} \\
(24.5)\end{array}$ & $\begin{array}{c}\mathbf{4 1 . 9} \\
(18.6)\end{array}$ & $\begin{array}{c}\mathbf{3 7 . 9} \\
(12.7)\end{array}$ & $\begin{array}{c}\mathbf{4 6 . 7} \\
(15.8)\end{array}$ & $\begin{array}{c}\mathbf{7 9 . 9} \\
(10.6)\end{array}$ & $\begin{array}{c}\mathbf{4 3 . 2} \\
(23.7)\end{array}$ & $\begin{array}{c}\mathbf{3 0 . 8} \\
(15.1)\end{array}$ & $\begin{array}{c}\mathbf{3 5 . 1} \\
(17.2)\end{array}$ & $\begin{array}{c}\mathbf{4 2 . 7} \\
(22.1)\end{array}$ & $\begin{array}{l}23.3 \\
(9.5)\end{array}$ & $\begin{array}{c}24.5 \\
(9.0)\end{array}$ & $\begin{array}{c}23.7 \\
(9.4)\end{array}$ & $\begin{array}{c}\mathbf{7 7 . 9} \\
(14.1)\end{array}$ \\
\hline $\begin{array}{l}\text { In salinity }>1 \\
\text { and }<5 \text { psu }\end{array}$ & $\begin{array}{c}\mathbf{1 . 9} \\
(1.8)\end{array}$ & $\begin{array}{c}41.7 \\
(24.5)\end{array}$ & $\begin{array}{c}\mathbf{5 4 . 6} \\
(19.3)\end{array}$ & $\begin{array}{c}\mathbf{4 8 . 3} \\
(13.2)\end{array}$ & $\begin{array}{c}\mathbf{4 8 . 7} \\
(17.1)\end{array}$ & $\begin{array}{l}\mathbf{1 3 . 3} \\
(6.4)\end{array}$ & $\begin{array}{c}\mathbf{4 7 . 8} \\
(18.6)\end{array}$ & $\begin{array}{c}\mathbf{5 2 . 2} \\
(3.6)\end{array}$ & $\begin{array}{c}\mathbf{5 6 . 2} \\
(15.0)\end{array}$ & $\begin{array}{c}\mathbf{4 6 . 5} \\
(15.6)\end{array}$ & $\begin{array}{c}\mathbf{4 0 . 3} \\
(12.9)\end{array}$ & $\begin{array}{c}\mathbf{4 5 . 9} \\
(12.3)\end{array}$ & $\begin{array}{c}\mathbf{4 1 . 1} \\
(12.7)\end{array}$ & $\begin{array}{c}\mathbf{1 3 . 8} \\
(6.7)\end{array}$ \\
\hline $\begin{array}{l}\text { In bottom } \\
\text { waters }\end{array}$ & $\begin{array}{c}\mathbf{5 7 . 1} \\
(13.7)\end{array}$ & $\begin{array}{c}\mathbf{6 6 . 2} \\
(11.5)\end{array}$ & $\begin{array}{c}\mathbf{5 1 . 4} \\
(14.2)\end{array}$ & $\begin{array}{l}\mathbf{7 0 . 9} \\
(3.5)\end{array}$ & $\begin{array}{c}\mathbf{5 5 . 4} \\
(12.6)\end{array}$ & $\begin{array}{c}\mathbf{5 3 . 2} \\
(8.2)\end{array}$ & $\begin{array}{c}\mathbf{6 2 . 9} \\
(5.8)\end{array}$ & $\begin{array}{c}\mathbf{5 1 . 5} \\
(15.1)\end{array}$ & $\begin{array}{c}\mathbf{5 8 . 3} \\
(18.5)\end{array}$ & $\begin{array}{l}\mathbf{5 7 . 1} \\
(9.8)\end{array}$ & $\begin{array}{c}\mathbf{5 5 . 4} \\
(15.7)\end{array}$ & $\begin{array}{c}\mathbf{6 2 . 1} \\
(10.0)\end{array}$ & $\begin{array}{c}\mathbf{5 6 . 2} \\
(15.0)\end{array}$ & $\begin{array}{c}33.5 \\
(0.6)\end{array}$ \\
\hline $\begin{array}{l}\text { In bottom and } \\
\text { mid-depth waters }\end{array}$ & $\begin{array}{c}\mathbf{8 5 . 6} \\
(8.4)\end{array}$ & $\begin{array}{c}85.2 \\
(7.6)\end{array}$ & $\begin{array}{c}\mathbf{7 3 . 1} \\
(13.3)\end{array}$ & $\begin{array}{c}\mathbf{8 6 . 2} \\
(5.6)\end{array}$ & $\begin{array}{c}\mathbf{7 4 . 5} \\
(13.2)\end{array}$ & $\begin{array}{l}\mathbf{7 7 . 6} \\
(6.8)\end{array}$ & $\begin{array}{c}\mathbf{8 6 . 4} \\
(2.6)\end{array}$ & $\begin{array}{c}\mathbf{7 6 . 8} \\
(14.2)\end{array}$ & $\begin{array}{c}\mathbf{7 6 . 0} \\
(14.6)\end{array}$ & $\begin{array}{c}\mathbf{8 1 . 1} \\
(8.0)\end{array}$ & $\begin{array}{l}\mathbf{7 4 . 8} \\
(9.0)\end{array}$ & $\begin{array}{c}\mathbf{8 1 . 3} \\
(6.3)\end{array}$ & $\begin{array}{l}\mathbf{7 5 . 6} \\
(8.7)\end{array}$ & $\begin{array}{c}\mathbf{6 1 . 7} \\
(2.2)\end{array}$ \\
\hline $\begin{array}{l}\text { In temperatures } \\
>15 \text { and }<20^{\circ} \mathrm{C}\end{array}$ & $\begin{array}{c}\mathbf{4 4 . 0} \\
(29.3)\end{array}$ & $\begin{array}{c}\mathbf{5 6 . 5} \\
(26.8)\end{array}$ & $\begin{array}{c}\mathbf{8 4 . 5} \\
(11.3)\end{array}$ & $\begin{array}{c}\mathbf{6 8 . 5} \\
(17.3)\end{array}$ & $\begin{array}{c}\mathbf{8 1 . 1} \\
(14.6)\end{array}$ & $\begin{array}{c}\mathbf{5 9 . 4} \\
(29.7)\end{array}$ & $\begin{array}{c}\mathbf{5 4 . 9} \\
(21.7)\end{array}$ & $\begin{array}{c}\mathbf{6 9 . 5} \\
(11.3)\end{array}$ & $\begin{array}{c}\mathbf{7 3 . 2} \\
(15.6)\end{array}$ & $\begin{array}{c}\mathbf{5 7 . 9} \\
(20.5)\end{array}$ & $\begin{array}{c}\mathbf{5 5 . 3} \\
(16.6)\end{array}$ & $\begin{array}{c}\mathbf{5 6 . 3} \\
(12.3)\end{array}$ & $\begin{array}{c}\mathbf{5 5 . 5} \\
(15.8)\end{array}$ & $\begin{array}{c}\mathbf{5 9 . 2} \\
(28.0)\end{array}$ \\
\hline 1999 & & & & & & & & & & & & & & \\
\hline $\begin{array}{l}\text { Within } 10 \mathrm{~km} \\
\text { of max. TSS }\end{array}$ & $\begin{array}{c}\mathbf{3 5 . 1} \\
(35.1)\end{array}$ & $\begin{array}{r}100.0 \\
(0.0)\end{array}$ & $\begin{array}{l}- \\
-\end{array}$ & $\begin{array}{l}- \\
-\end{array}$ & $\begin{array}{l}- \\
-\end{array}$ & $\begin{array}{c}\mathbf{6 2 . 7} \\
(12.5)\end{array}$ & $\begin{array}{c}\mathbf{4 4 . 9} \\
(12.1)\end{array}$ & $\begin{array}{c}\mathbf{4 6 . 5} \\
(30.2)\end{array}$ & $\begin{array}{l}\mathbf{0 . 0} \\
-\end{array}$ & $\begin{array}{c}\mathbf{4 2 . 4} \\
(17.9)\end{array}$ & $\begin{array}{c}\mathbf{6 0 . 5} \\
(10.2)\end{array}$ & $\begin{array}{c}\mathbf{5 4 . 1} \\
(13.9)\end{array}$ & $\begin{array}{c}\mathbf{5 9 . 7} \\
(10.7)\end{array}$ & $\begin{array}{c}\mathbf{2 9 . 9} \\
(13.0)\end{array}$ \\
\hline $\begin{array}{l}\text { In salinity } \\
<1 \mathrm{psu}\end{array}$ & $\begin{array}{c}30.5 \\
-\end{array}$ & $\begin{array}{l}\mathbf{0 . 0} \\
-\end{array}$ & $\begin{array}{l}- \\
-\end{array}$ & - & - & $\begin{array}{c}39.4 \\
-\end{array}$ & $\begin{array}{c}24.6 \\
-\end{array}$ & $\begin{array}{c}12.0 \\
-\end{array}$ & $\begin{array}{l}- \\
-\end{array}$ & $\begin{array}{c}22.5 \\
-\end{array}$ & $\begin{array}{l}7.3 \\
-\end{array}$ & $\begin{array}{l}7.5 \\
-\end{array}$ & $\begin{array}{l}7.3 \\
-\end{array}$ & $\begin{array}{c}74.2 \\
-\end{array}$ \\
\hline $\begin{array}{l}\text { In salinity }>1 \\
\text { and }<5 \text { psu }\end{array}$ & $\begin{array}{c}\mathbf{8 4 . 8} \\
(15.2)\end{array}$ & $\begin{array}{c}\mathbf{5 0 . 0} \\
(50.0)\end{array}$ & $\begin{array}{l}- \\
-\end{array}$ & $\begin{array}{l}- \\
-\end{array}$ & $\begin{array}{l}- \\
-\end{array}$ & $\begin{array}{c}\mathbf{5 3 . 9} \\
(38.8)\end{array}$ & $\begin{array}{c}\mathbf{6 3 . 9} \\
(32.9)\end{array}$ & $\begin{array}{c}\mathbf{7 2 . 1} \\
(27.9)\end{array}$ & $\begin{array}{c}100.0 \\
-\end{array}$ & $\begin{array}{c}\mathbf{6 5 . 6} \\
(32.3)\end{array}$ & $\begin{array}{c}\mathbf{5 0 . 6} \\
(27.1)\end{array}$ & $\begin{array}{c}\mathbf{4 3 . 4} \\
(27.2)\end{array}$ & $\begin{array}{c}\mathbf{4 9 . 9} \\
(26.9)\end{array}$ & $\begin{array}{c}\mathbf{6 0 . 3} \\
(39.7)\end{array}$ \\
\hline $\begin{array}{l}\text { In bottom } \\
\text { waters }\end{array}$ & $\begin{array}{c}4.0 \\
(4.0)\end{array}$ & $\begin{array}{c}\mathbf{0 . 0} \\
(0.0)\end{array}$ & $\begin{array}{l}- \\
-\end{array}$ & $\begin{array}{l}- \\
-\end{array}$ & $\begin{array}{l}- \\
-\end{array}$ & $\begin{array}{c}\mathbf{3 7 . 7} \\
(5.6)\end{array}$ & $\begin{array}{c}23.9 \\
(8.0)\end{array}$ & $\begin{array}{c}\mathbf{1 8 . 3} \\
(9.6)\end{array}$ & $\begin{array}{c}66.6 \\
-\end{array}$ & $\begin{array}{c}\mathbf{2 5 . 7} \\
(11.0)\end{array}$ & $\begin{array}{l}41.1 \\
(1.0)\end{array}$ & $\begin{array}{c}\mathbf{5 0 . 3} \\
(4.0)\end{array}$ & $\begin{array}{l}42.0 \\
(1.0)\end{array}$ & $\begin{array}{c}\mathbf{2 8 . 7} \\
(15.6)\end{array}$ \\
\hline $\begin{array}{l}\text { In bottom and } \\
\text { mid-depth waters }\end{array}$ & $\begin{array}{c}\mathbf{6 9 . 4} \\
(0.1)\end{array}$ & $\begin{array}{r}100.0 \\
(0.0)\end{array}$ & $\begin{array}{l}- \\
-\end{array}$ & $\begin{array}{l}- \\
-\end{array}$ & $\begin{array}{l}- \\
-\end{array}$ & $\begin{array}{c}\mathbf{7 0 . 6} \\
(0.6)\end{array}$ & $\begin{array}{c}\mathbf{5 9 . 3} \\
(3.4)\end{array}$ & $\begin{array}{l}49.7 \\
(5.4)\end{array}$ & $\begin{array}{c}66.6 \\
-\end{array}$ & $\begin{array}{c}\mathbf{5 8 . 4} \\
(3.0)\end{array}$ & $\begin{array}{c}\mathbf{6 6 . 0} \\
(6.8)\end{array}$ & $\begin{array}{l}\mathbf{7 5 . 0} \\
(10.1)\end{array}$ & $\begin{array}{c}\mathbf{6 6 . 8} \\
(7.0)\end{array}$ & $\begin{array}{c}\mathbf{3 6 . 1} \\
(17.2)\end{array}$ \\
\hline $\begin{array}{l}\text { In temperatures } \\
>15 \text { and }<20^{\circ} \mathrm{C}\end{array}$ & $\begin{array}{r}100.0 \\
(0.0)\end{array}$ & $\begin{array}{c}\mathbf{5 0 . 0} \\
(50.0)\end{array}$ & $\begin{array}{l}- \\
-\end{array}$ & $\begin{array}{l}- \\
-\end{array}$ & $\begin{array}{l}- \\
-\end{array}$ & $\begin{array}{l}\mathbf{7 3 . 3} \\
(25.9)\end{array}$ & $\begin{array}{c}\mathbf{6 9 . 9} \\
(26.9)\end{array}$ & $\begin{array}{c}\mathbf{6 1 . 7} \\
(38.3)\end{array}$ & $\begin{array}{c}100.0 \\
-\end{array}$ & $\begin{array}{c}\mathbf{6 8 . 8} \\
(29.1)\end{array}$ & $\begin{array}{c}\mathbf{5 6 . 0} \\
(40.3)\end{array}$ & $\begin{array}{c}\mathbf{5 5 . 9} \\
(38.2)\end{array}$ & $\begin{array}{c}\mathbf{5 6 . 0} \\
(40.1)\end{array}$ & $\begin{array}{c}\mathbf{8 8 . 9} \\
(11.1)\end{array}$ \\
\hline
\end{tabular}


Table 2. Multiple regression tables for potential prey and early-life stages of striped bass Morone saxatilis and white perch M. saxatilis in 1998 gradient-mapping surveys, showing parameter estimates (Param. est.) for variables that described a significant ( $\alpha=0.05)$ amount of variability in organism concentrations. (SEs in parentheses). F: F-statistic; p: probability; ns: not significant; s: surface tow; m: mid-depth tow. Axial distance: distance from Susquehanna River mouth. Salinity, total suspended solids (TSS) concentrations, and 'Above ETM' were modeled as dichotomous variables ( 0 when salinity $<1 \mathrm{psu}$ TSS $<47 \mathrm{mg} \mathrm{l}^{-1}$, or when station was within or up-estuary of maximum TSS concentrations, otherwise 1). All organism concentrations were $\log _{\mathrm{e}}$-transformed. -: Fixed effects not included in model. Sample size (n) $=49$ for all models

\begin{tabular}{|c|c|c|c|c|c|c|c|c|c|c|c|c|}
\hline Explanatory variables & $F$ & $\mathrm{p}$ & Param. est. & $F$ & $\mathrm{p}$ & Param. est. & $F$ & $\mathrm{p}$ & Param. est. & $F$ & $\mathrm{p}$ & Param. est. \\
\hline $\begin{array}{l}\text { a) Striped bass } \\
\text { early-life stages }\end{array}$ & \multicolumn{3}{|c|}{ Eggs } & \multicolumn{3}{|c|}{ Yolk-sac larvae } & \multicolumn{3}{|c|}{ Larvae $5-8 \mathrm{~mm}$} & \multicolumn{3}{|c|}{ Larvae 8-10 mm } \\
\hline Salinity & 0.00 & 0.96 & ns & 2.84 & 0.11 & $\mathrm{~ns}$ & 0.02 & 0.90 & $\mathrm{~ns}$ & 0.79 & 0.38 & $\mathrm{~ns}$ \\
\hline Temperature & 0.38 & 0.56 & ns & 0.36 & 0.55 & ns & 0.08 & 0.78 & ns & 0.00 & 0.99 & ns \\
\hline TSS & 0.23 & 0.63 & $\mathrm{~ns}$ & 0.39 & 0.54 & ns & 5.68 & 0.03 & $1.72(0.72)$ & 1.14 & 0.30 & ns \\
\hline Tow depth & 3.03 & 0.08 & $\mathrm{~ns}$ & 0.74 & 0.50 & ns & 0.25 & 0.78 & ns & 1.46 & 0.27 & ns \\
\hline Distance from ETM & 2.55 & 0.14 & $\mathrm{~ns}$ & 3.40 & 0.09 & ns & 14.79 & 0.01 & $-0.09(0.02)$ & 0.46 & 0.52 & ns \\
\hline Axial distance & 4.77 & 0.04 & $-0.09(0.04)$ & 0.69 & 0.42 & ns & 0.03 & 0.86 & $\mathrm{~ns}$ & 0.94 & 0.34 & ns \\
\hline All Eurytemora affinis & - & - & - & - & - & - & 3.19 & 0.10 & ns & 4.89 & 0.04 & $0.41(0.18)$ \\
\hline Bosmina longirostris & - & - & - & - & - & - & 17.02 & $<0.001$ & $0.58(0.14)$ & 5.30 & 0.03 & $0.30(0.13)$ \\
\hline $\begin{array}{l}\text { b) White perch } \\
\text { early-life stages }\end{array}$ & \multicolumn{3}{|c|}{ Yolk-sac larvae } & \multicolumn{3}{|c|}{ Larvae $<5 \mathrm{~mm}$} & \multicolumn{3}{|c|}{ Larvae 5-8 mm } & \multicolumn{3}{|c|}{ Larvae 8-10 mm } \\
\hline Salinity & 0.07 & 0.79 & $\mathrm{~ns}$ & 3.52 & 0.08 & ns & 1.58 & 0.22 & $\mathrm{~ns}$ & 1.45 & 0.26 & ns \\
\hline Temperature & 0.38 & 0.69 & ns & 0.54 & 0.47 & ns & 1.34 & 0.26 & ns & 0.14 & 0.72 & ns \\
\hline TSS & 0.30 & 0.60 & $\mathrm{~ns}$ & 0.00 & 0.99 & ns & 0.48 & 0.50 & ns & 0.89 & 0.36 & $\mathrm{~ns}$ \\
\hline Tow depth & 0.80 & 0.47 & ns & 1.75 & 0.20 & ns & 0.82 & 0.46 & ns & 0.39 & 0.69 & $\mathrm{~ns}$ \\
\hline Distance from ETM & 0.04 & 0.84 & ns & 1.12 & 0.31 & ns & 2.16 & 0.17 & $\mathrm{~ns}$ & 0.57 & 0.46 & ns \\
\hline Axial distance & 16.50 & $<0.001$ & $-0.13(0.03)$ & 1.53 & 0.23 & ns & 4.23 & 0.06 & ns & 0.12 & 0.73 & ns \\
\hline Copepodites & - & - & - & 4.70 & 0.04 & $0.43(0.19)$ & - & - & - & - & - & - \\
\hline All Eurytemora affinis & - & - & - & - & - & - & 8.14 & 0.01 & $0.62(0.21)$ & 15.05 & $<0.01$ & $0.81(0.20)$ \\
\hline Bosmina longirostris & - & - & - & 3.80 & 0.07 & ns & 7.11 & 0.02 & $0.42(0.15)$ & 4.81 & 0.04 & $0.34(0.15)$ \\
\hline $\begin{array}{l}\text { c) Potential zoo- } \\
\text { plankton prey }\end{array}$ & \multicolumn{3}{|c|}{$\begin{array}{c}\text { Eurytemora affinis } \\
\text { Copepodites and adult males }\end{array}$} & \multicolumn{3}{|c|}{$\begin{array}{l}\text { Eurytemora affinis } \\
\text { Adult females }\end{array}$} & \multicolumn{3}{|c|}{ Bosmina longirostris } & & & \\
\hline Salinity & 4.72 & 0.04 & $1.37(0.63)$ & 2.09 & 0.16 & $\mathrm{~ns}$ & 1.38 & 0.29 & ns & & & \\
\hline Temperature & 1.77 & 0.20 & ns & 0.76 & 0.42 & ns & 0.08 & 0.78 & ns & & & \\
\hline TSS & 0.06 & 0.81 & $\mathrm{~ns}$ & 0.00 & 0.95 & ns & 5.42 & 0.06 & ns & & & \\
\hline Tow depth & 5.14 & 0.02 & $\begin{array}{l}-0.86(0.49) \mathrm{s} \\
-1.02(0.33) \mathrm{m}\end{array}$ & 2.00 & 0.17 & ns & 23.16 & $<0.001$ & $\begin{array}{l}5.83(1.23) \mathrm{s} \\
3.14(0.43) \mathrm{m}\end{array}$ & & & \\
\hline Distance from ETM & 4.68 & 0.05 & $-0.06(0.03)$ & 12.41 & 0.01 & $-0.11(0.03)$ & 1.63 & 0.23 & ns & & & \\
\hline Axial distance & 2.89 & 0.10 & $\mathrm{~ns}$ & 2.27 & 0.14 & $\mathrm{~ns}$ & - & - & - & & & \\
\hline Above ETM & - & - & - & - & - & - & 7.22 & 0.03 & $-4.01(1.39)$ & & & \\
\hline Above ETM $\times$ Tow depth & - & - & - & - & - & - & 33.98 & $<0.0001$ & $1.13(0.18)$ & & & \\
\hline
\end{tabular}

and white perch post-yolk-sac larval stages, apparently because striped bass yolk-sac and post-yolk-sac larvae were more concentrated within the ETM (Fig. 4) and farther up-estuary (Figs. $5 \& 6$ ) than white perch post-yolk-sac larvae. For striped bass larvae of 5 to $8 \mathrm{~mm}$ in 1998, TSS concentrations and distance from the ETM were significant in the multiple-regression model, indicating that these larvae tended to occur near the ETM in waters with TSS $>47 \mathrm{mg} \mathrm{l}^{-1}$ (Table 2).

For each species, significant overlap occurred between larval stages. For example, white perch postyolk-sac larvae $<5 \mathrm{~mm}$ overlapped with 5 to $8 \mathrm{~mm}$ larvae in $1999(71 \% \pm 2 \mathrm{SE})$ and 5 to $8 \mathrm{~mm}$ larvae overlapped with 8 to $10 \mathrm{~mm}$ larvae in 1998 (77\% $\% 8 \mathrm{SE})$. In 1998, the overlap index between striped bass yolk-sac and 8 to $10 \mathrm{~mm}$ larvae $(66 \% \pm 5 \mathrm{SE})$ was significant. Although there was significant overlap of stages within species, there were stage-specific differences. For example, $<5 \mathrm{~mm}$ white perch larvae had distributions intermediate between yolk-sac larvae and later stage post-yolk-sac larvae (Fig. 5e-g), and post-yolk-sac larvae became more concentrated within the ETM region with increasing development (Fig. 4e-h). Striped bass post-yolk-sac larvae also showed stage-specific differences in distribution during some (Fig. 6a,b), but not all (Fig. 5b,c), cruises.

Consistent patterns were also evident in the distribution of the copepod Eurytemora affinis copepods and the cladoceran Bosmina longirostris. Both stages and sexes of E. affinis generally peaked in abundance 

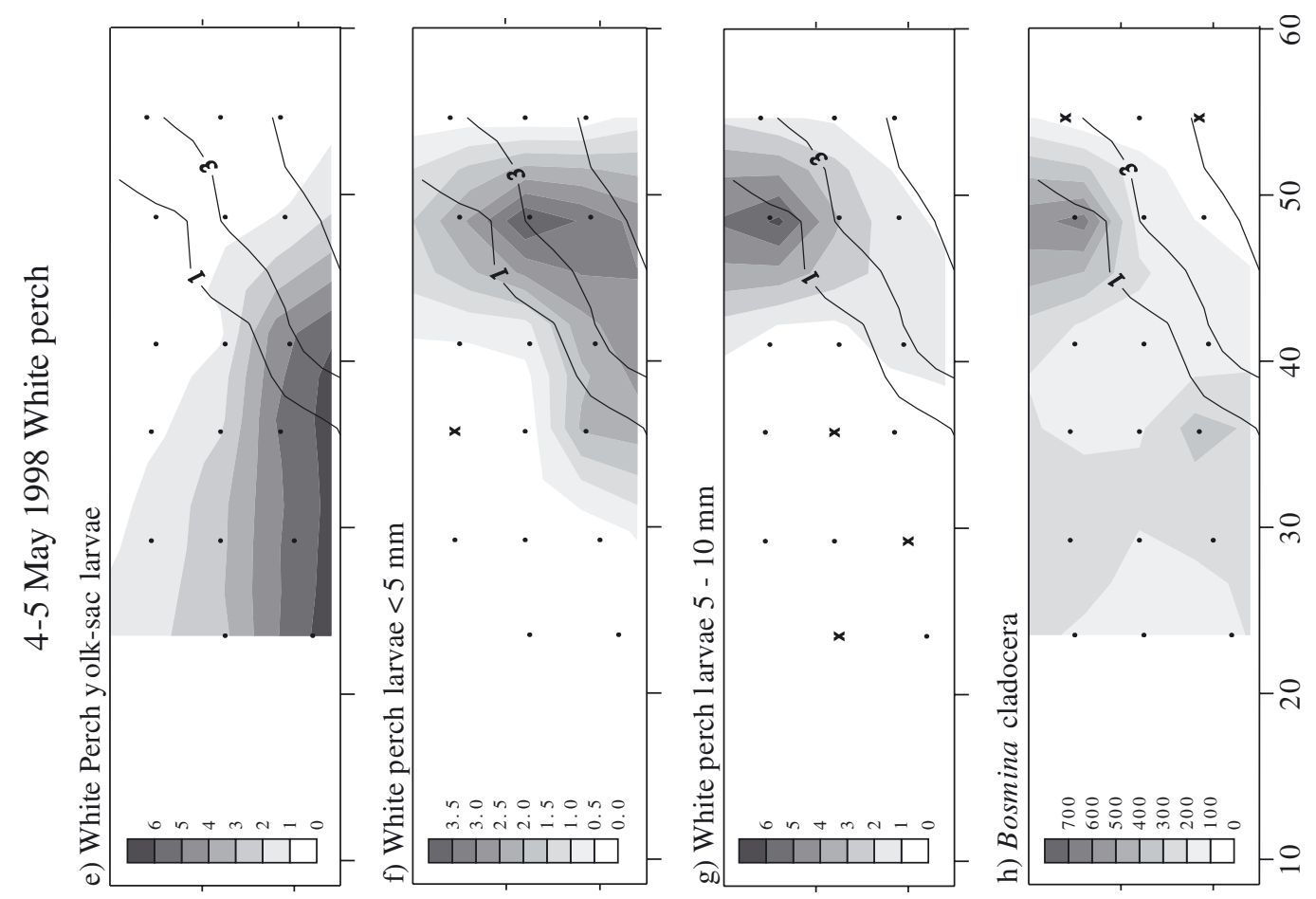

虽

궁

寻弯

ชิ

웡 웜

논

式考

하

कृ

品 :

तี

:

శซ
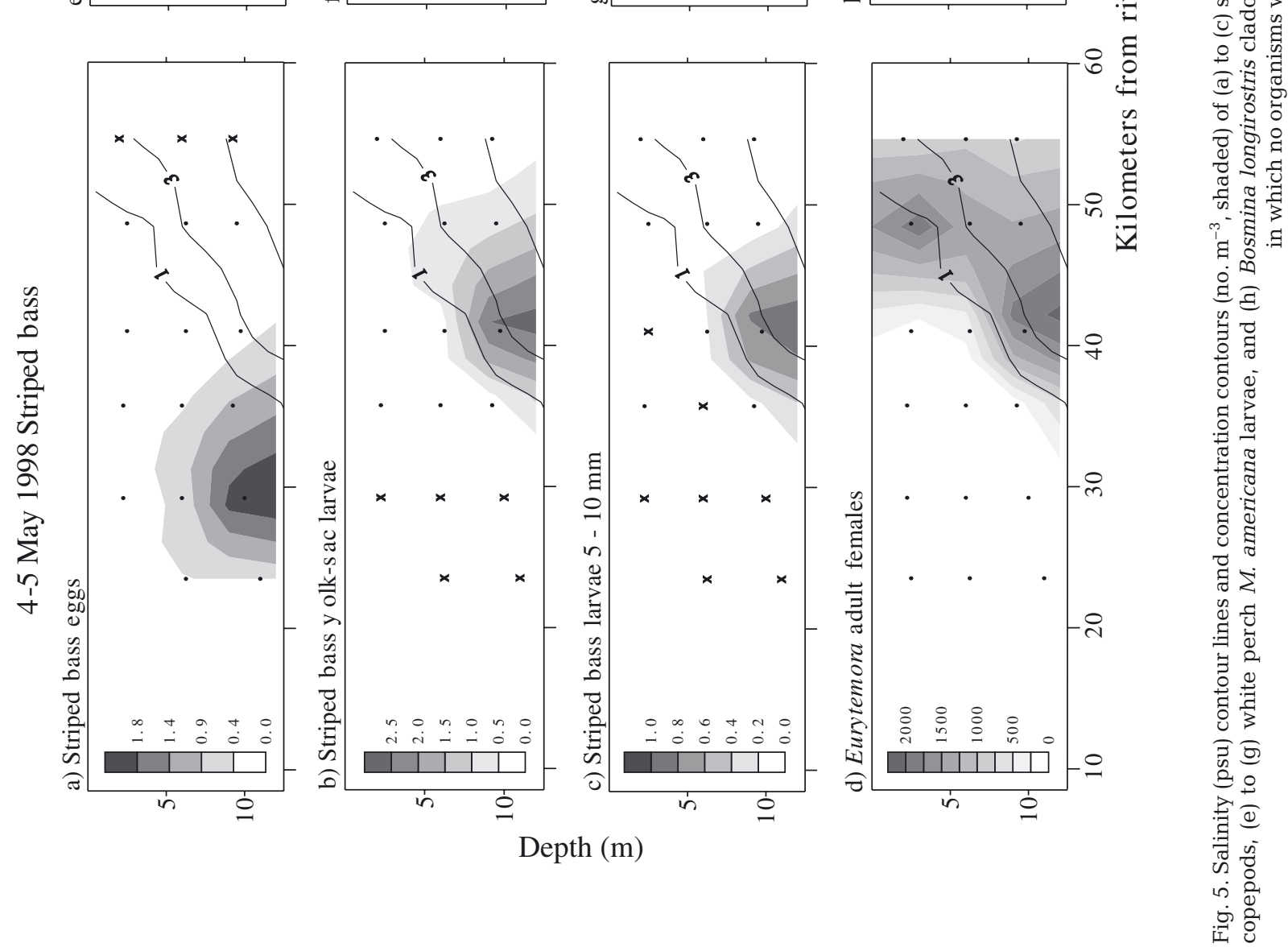

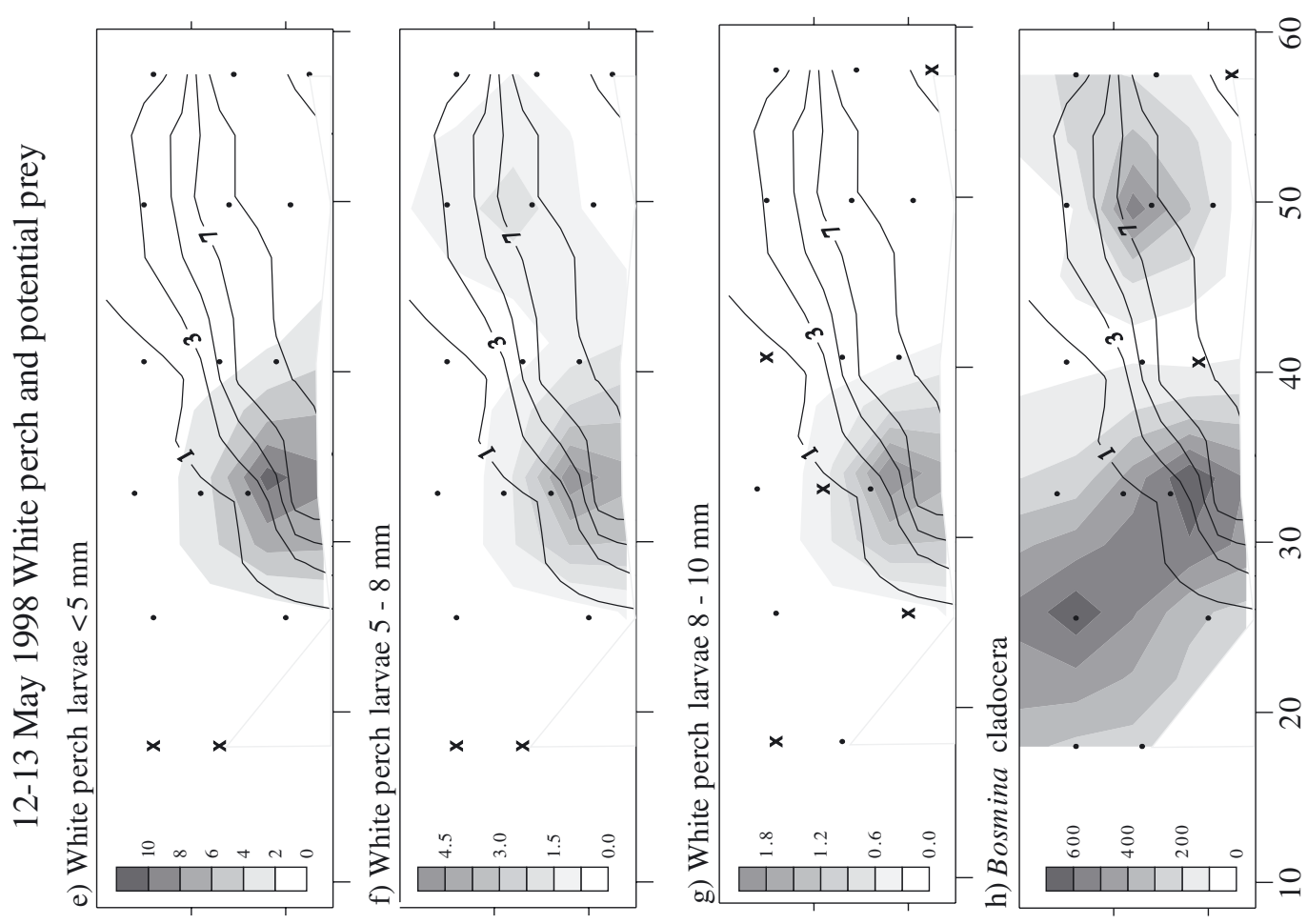

范

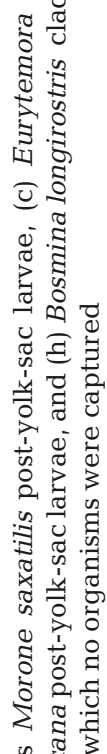

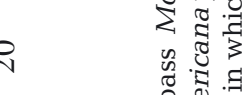

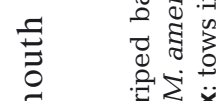

E $\quad$ 教

$\dot{0} \quad$ के च्च

ब

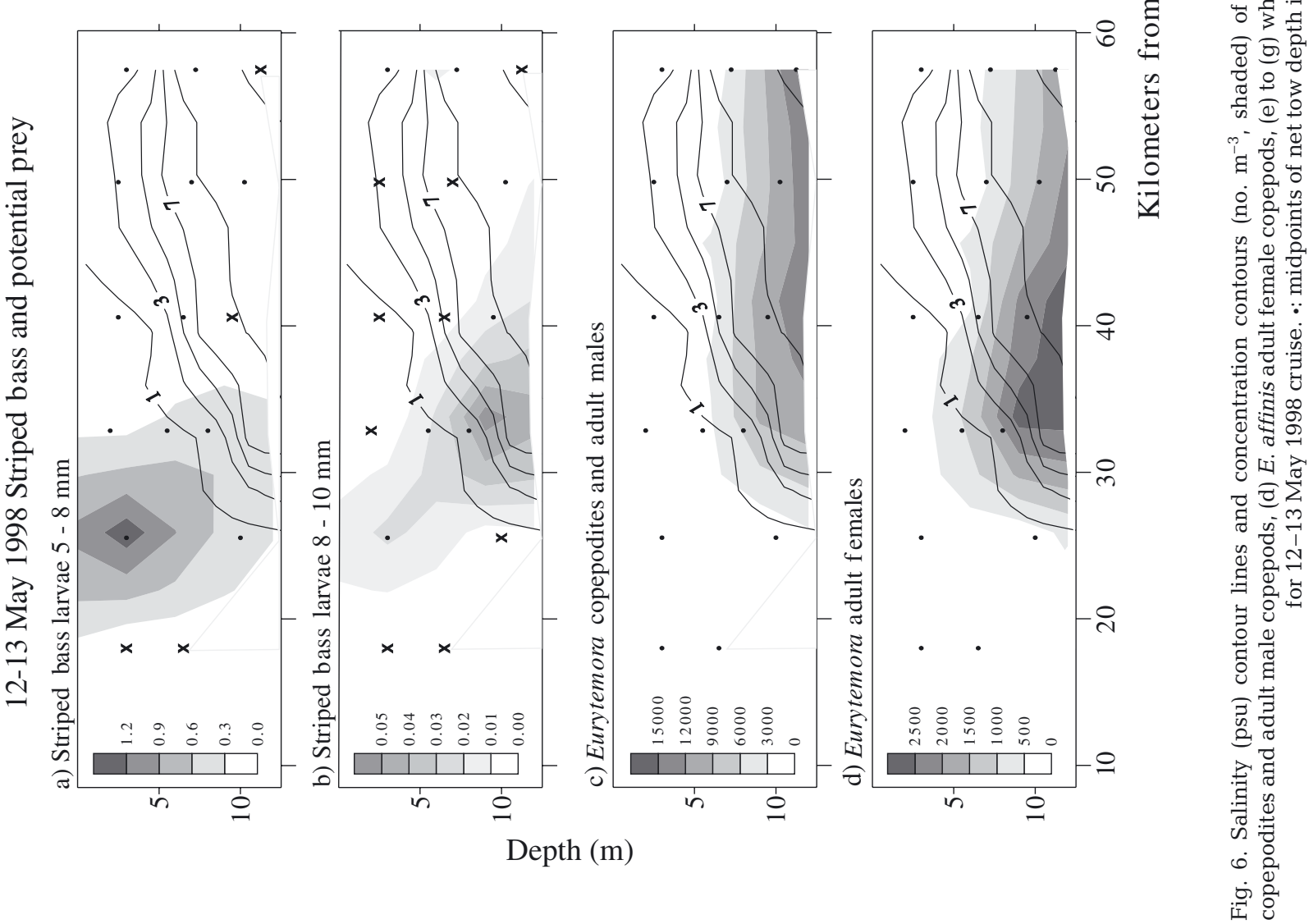


a) Eurytemora copepodites and males

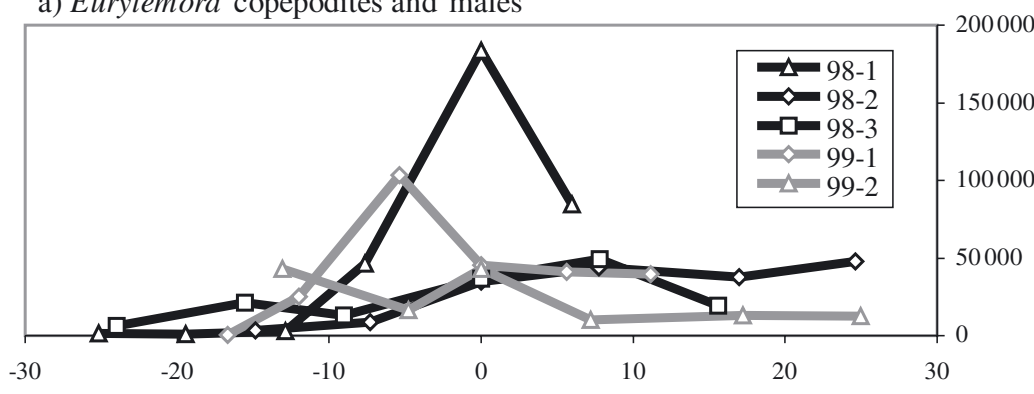

b) Eurytemora adult females

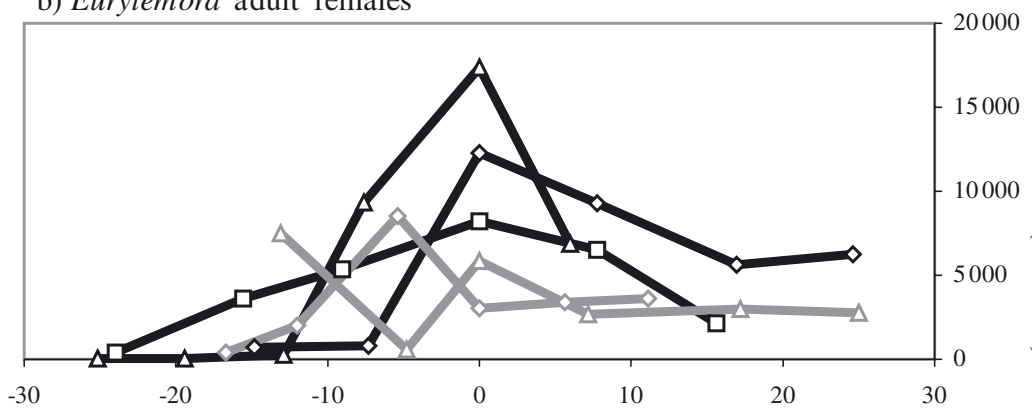

c) Bosmina

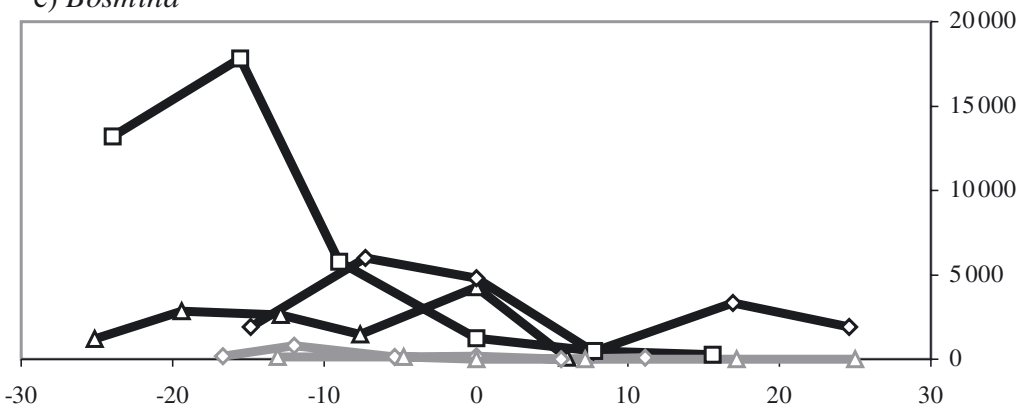

Kilometers from maximum TSS

Fig. 7. (a) Eurytemora affinis copepodites and adult males; (b) E. affinis adult females; (c) Bosmina longirostris cladocera. Abundance relative to distance from maximum TSS measurements for each cruise in 1998 (98-1, 98-2, 98-3) and 1999 (99-1, 99-2). Negative numbers indicate distance up-estuary of maximum TSS

within $10 \mathrm{~km}$ of maximum TSS concentrations (Fig. $7 a, b)$. In 1998, more than $70 \%$ of E. affinis copepodites and adult copepods occurred within $10 \mathrm{~km}$ of maximum TSS concentrations in mid-depth and bottom waters and in salinities $>1$ psu (Table 1). This pattern was also apparent in 1999, although not as strongly (Table 1). Distance from the ETM center was significant in regression models for E. affinis copepodites and males, and adult females, indicating that their concentrations peaked in the ETM region in 1998 (Table 2c). In addition, salinity and depth described a significant amount of variability in E. affinis cope- podite and adult male concentrations, indicating that these stages were mostly found near-bottom in salinities $>1$ psu. In contrast, most $(>74 \%)$ B. longirostris cladocera were found in salinities $<1 \mathrm{psu}$ (Table 1) and did not consistently peak in abundance in the ETM region during either year (Fig. 7c). The interaction between depth and 'above ETM' (coded either up- or down-estuary of the ETM) was the most significant factor in the $B$. longirostris regression model, indicating that $B$. longirostris declined in concentrations and differed in depths of occurrence from up-estuary to down-estuary of the ETM in 1998 (Table 2c).

Peak concentrations of feeding larvae generally coincided with high concentrations of potential prey for both striped bass and white perch larvae (Figs. 5, 6 \& 8). In 1998, prey concentrations accounted for most of the variability in concentrations of striped bass and white perch post-yolk-sac larval concentrations in multiple-regression models (Table 2a,b). Although Bosmina longirostris was a significant factor in models for 5 to $10 \mathrm{~mm}$ striped bass and white perch larvae, Eurytemora affinis copepods described more of the variance in white perch post-yolk-sac larval concentrations for all size classes (Table 2b). In contrast, B. longirostris described more of the variability in striped bass post-yolksac larvae concentrations than did E. affinis copepods (Table 2a). In general, variability in the concentrations of feeding larvae was strongly accounted for by prey whose distributions peaked in concentration in the ETM region (i.e. E. affinis), or, in the case of 5 to $8 \mathrm{~mm}$ striped bass larvae, by $B$. longirostris concentrations coupled with physical (TSS concentrations) and spatial (distance from ETM) factors that indicated larval concentrations peaked in the ETM region.

Significant overlap indices also showed the close association between the spatial distributions of feeding larvae and their potential prey. There was significant overlap between white perch larvae and Eurytemora affinis copepods in both years. In 1998, 5 to $8 \mathrm{~mm}$ larvae $(61 \% \pm 8 \mathrm{SE})$ and 8 to $10 \mathrm{~mm}$ larvae $(58 \% \pm 10 \mathrm{SE})$ overlapped with E. affinis adult females. In 1999, $<5 \mathrm{~mm}$ white perch larvae overlapped with E. affinis copepodites and adult males $(61 \% \pm 0.0 \mathrm{SE})$ and adult 
females $(58 \% \pm 0.2 \mathrm{SE})$, and 5 to $8 \mathrm{~mm}$ larvae overlapped with $E$. affinis copepodites and adult males $(49 \% \pm 10 \mathrm{SE})$. For striped bass in 1998, significant overlap occurred between 8 to $10 \mathrm{~mm}$ larvae and E. affinis adult females $(56 \% \pm 4 \mathrm{SE})$. The lack of significant overlap in other stages may have occurred because peak concentrations of larval stages did not consistently coincide with peak concentrations of the same prey species during all cruises. For example, peak concentrations of 5 to $8 \mathrm{~mm}$ striped bass larvae overlapped with high $E$. affinis concentrations during the first cruise in 1998 (Fig. 5c,d) but coincided with the peak in Bosmina longirostris concentration during the second cruise in 1998 (Fig. 6a,h).

Relatively consistent patterns in fish early-life stages and zooplankton distributions occurred despite notable variation in physical conditions between and within years. This outcome was observed because organism distributions tracked changes in the location of the salt front and ETM. For example, peak concentrations of striped bass and white perch postyolk-sac larvae shifted 10 to $20 \mathrm{~km}$ up-estuary when the salt front moved up-estuary between the first and second cruise in 1998 (cf. Figs. 5 \& 6). Peak concentrations of Eurytemora affinis and Bosmina longirostris followed the same pattern (Figs. 5 \& 6). When the salt front was located far up-estuary during low freshwater flow in 1999, fish larvae and their potential prey were found in peak concentrations near the salt front, well up-estuary of their locations in 1998 (Fig. 8).

\section{Stock-recruitment models}

The abundances of YOY striped bass and white perch from the juvenile striped bass seine survey had trends similar to larval abundances: lower in 1999 (a low freshwater flow year) than in 1998 (a high-flow year). Correlation analyses between YOY abundance and spring Susquehanna River discharge previously had demonstrated that this general relationship held for the YOY time series (1987 to 1999) (North \& Houde 2001). The positive correlation between white perch YOY and freshwater discharge was notable $(\mathrm{r}=0.54, \mathrm{n}$ $=13, p=0.057$ ), while the correlation between striped bass YOY and freshwater discharge was strong and significant (striped bass: $\mathrm{r}=0.73, \mathrm{n}=13, \mathrm{p}=0.005$ ). In contrast, correlations between spawning-stock abundance indices and discharge (1987 to 1999) for these species were not significant (striped bass: $\mathrm{r}=-0.24, \mathrm{n}=$ $13, \mathrm{p}=0.43$; white perch: $\mathrm{r}=-0.06, \mathrm{n}=13, \mathrm{p}=0.86$ ). The correlation between striped bass and white perch spawning-stock abundance indices also was not significant $(\mathrm{r}=0.34, \mathrm{n}=13, \mathrm{p}=0.26)$.
Parameter estimates and model-fit information for Ricker stock-recruit models and Ricker models incorporating discharge indicated that Ricker models incorporating discharge explained an additional $41 \%$ (striped bass, adjusted $\mathrm{R}^{2}=0.44$ ) and $30 \%$ (white perch, adjusted $\mathrm{R}^{2}=0.67$ ) of the variance in YOY recruitment than did the models with spawning-stock abundance alone (Table 3). In addition, the Akaike's Information Criteria differences indicated that models incorporating discharge provided a substantially better fit to the data than the Ricker models without discharge. Although it appears that the white perch models fit better than the striped bass models (higher

4-5 May 1999 White perch and potential prey

a) White perch larvae $<5 \mathrm{~mm}$

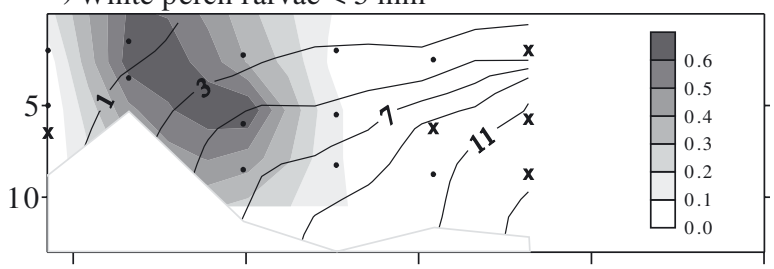

b) Eurytemora copepodites and adult males

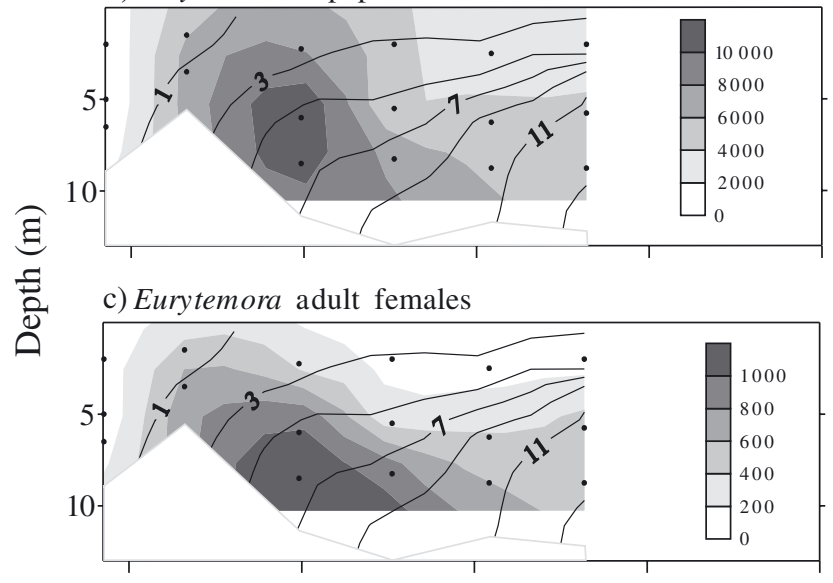

d) Bosmina cladocera

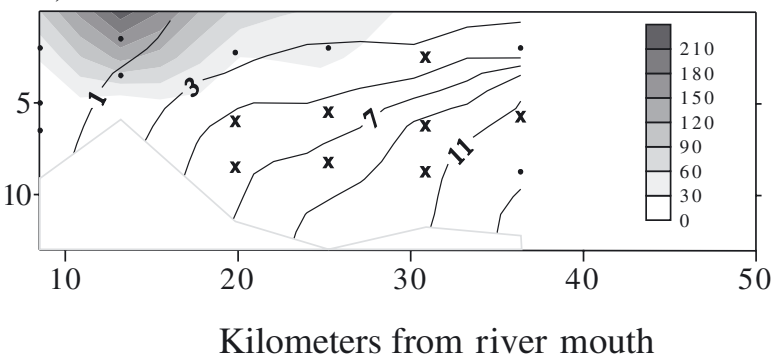

Fig. 8. Salinity (psu) contour lines and concentration contours (no. $\mathrm{m}^{-3}$, shaded) of (a) white perch Morone americana larvae $<5 \mathrm{~mm}$, (b) Eurytemora affinis copepodites and adult male copepods, (c) E. affinis adult female copepods, and (d) Bosmina longirostris cladocera for 4-5 May 1999 cruise. $\bullet:$ midpoints of net tow depth intervals; $\mathbf{x}$ : tows in which no organisms were captured 
Table 3. Morone saxatilis and M. americana. Parameters $(a, b, c)$ and nonlinear model-fit information for striped bass and white perch spawner-recruitment models. Ricker spawner-recruitment models $\left(R=a S \mathrm{e}^{-b S}\right)$ and Ricker models with spring freshwater discharge $\left(R=a S \mathrm{e}^{-b S-c D}\right)$ were fit to indices of upper Chesapeake Bay young-of-the-year recruitment $(R)$, spawning stock abundance $(S)$, and discharge $(D)$ from 1987 to 1999. Minimum Akaike's Information Criteria (AIC $_{c}$ ) values indicate model that best fits the data for each species. Models with $\mathrm{AIC}_{C}$ differences $\left(\Delta=\mathrm{AIC}_{C}-\right.$ minimum $\left.\mathrm{AIC}\right) \leq 2$ have substantial support while those with $4<\Delta<7$ have considerably less support (Burnham \& Anderson 1998). Sample size (n) was 13. SE = standard error

\begin{tabular}{|c|c|c|c|c|c|c|c|}
\hline \multirow{2}{*}{$\begin{array}{l}\text { Species } \\
\text { White perch }\end{array}$} & \multirow{2}{*}{$\begin{array}{l}\text { Model } \mathrm{SE}_{a} \\
R=a S \mathrm{e}^{-b S} \\
R=a S \mathrm{e}^{-b S-c D}\end{array}$} & \multirow[t]{2}{*}{$\mathrm{SE}_{b}$} & \multicolumn{2}{|c|}{$\mathrm{SE}_{c}$ Adjusted $\mathrm{R}^{2}$} & \multicolumn{3}{|c|}{$\mathrm{AIC}_{c} \mathrm{AIC}_{c}$ differences $(\Delta)$} \\
\hline & & & & & & & \\
\hline Ricker model & $R=7.97 S \mathrm{e}^{-0.01 S}$ & 3.330 & 0.030 & - & 0.37 & 92.41 & 5.23 \\
\hline Ricker model with discharge & $R=1.92 S \mathrm{e}^{-0.02 S+0.07 \mathrm{D}}$ & 1.370 & 0.020 & 0.020 & 0.67 & 87.18 & 0.00 \\
\hline \multicolumn{8}{|l|}{ Striped bass } \\
\hline Ricker model & $R=9.36 S \mathrm{e}^{-0.27 S}$ & 4.470 & 0.110 & - & 0.03 & 63.59 & 4.14 \\
\hline Ricker model with discharge & $R=2.90 S \mathrm{e}^{-0.26 S+0.05 D}$ & 1.940 & 0.100 & 0.020 & 0.44 & 59.45 & 0.00 \\
\hline
\end{tabular}

adjusted $\mathrm{R}^{2}$ ), this may be misleading because the adjusted $\mathrm{R}^{2}$ values for the white perch models were inflated by a single data point (1996) that resulted in a better model fit at high spawning stock sizes.

\section{DISCUSSION}

The ETM region is an important nursery area for striped bass and white perch, where larvae are retained in a region of elevated prey concentrations. On short timescales, the location of the salt front and ETM influences the distribution of passively transported fish early-life stages as well as Eurytemora affinis and Bosmina longirostris. The latter, major prey items of striped bass and white perch larvae, influence the distribution of feeding larvae. On seasonal time scales, freshwater flow influences the characteristics of the salt front and biological community within the ETM region, and is correlated with patterns in juvenile striped bass and white perch recruitment. We suggest that changes in freshwater flow affect (1) larval retention within the ETM nursery area, (2) the distribution and production of zooplankton prey and, subsequently, (3) larval striped bass and white perch survival and recruitment.

Within years, wind and freshwater discharge events influenced the location of the salt front, ETM, and the associated planktonic community in the upper Chesapeake Bay. Shifts in population location in relation to changes in the salt front have also been reported for anadromous fish larvae in the Hudson River. For example, Dew \& Hecht (1994) reported a high correlation $(r=0.82)$ between the movement of the salt front and peak concentrations of larvae of the Atlantic tomcod Microgadus tomcod. They hypothesized that freshwater flow controlled the location of the salt front in the Hudson River and its associated larval fish population.
The consistent peaks in striped bass yolk-sac larval abundances in the ETM region near the tip of the salt front in this and other studies (Secor et al. 1995, Robichaud-LeBlanc et al. 1996) suggest that transport of eggs down-estuary and passive retention of yolk-sac larvae in the ETM convergence zone may be an important component of the striped bass life-history strategy. Passive retention of early stages in the ETM convergence zone may not be as critical for white perch, because transport down-estuary occurs during the yolk-sac larval stage, when early development of a swimbladder in this species may permit larvae to actively control their position in the water column. This ability may allow them to exploit high prey concentrations as soon as they enter the ETM region in addition to facilitating their retention within it.

High concentrations of zooplankton prey may be an important and ubiquitous characteristic of ETM nursery areas. Similar to results of this study, peak abundances of Eurytemora affinis also were located within the ETM region in the Columbia River estuary (Simenstad et al. 1994), the San Francisco Bay estuary (Kimmerer et al. 1998), and in the upper Chesapeake Bay in 1996 (Roman et al. 2001). In addition, evidence suggests that E. affinis was associated with the ETM in the Gironde estuary in France (Castel \& Veiga 1990).

Striped bass and white perch early-life histories may be adapted to exploit the consistently high concentrations of zooplankton that occur within the ETM region. First-feeding striped bass are susceptible to starvation (Setzler-Hamilton et al. 1987), grow faster in high versus low prey concentrations (Chesney 1989, Chick \& Van Den Avyle 1999), and may require high prey concentrations to offset the energetic cost of osmoregulation in low-salinity waters near the salt front (Hirai 2002). In our study, the distribution of feeding larvae was related to variations in prey distributions, indicating that feeding larvae coincident with high prey con- 
centrations were survivors (a result of passive accumulation processes), and/or that later-stage feeding larvae may have actively tracked high prey concentrations (a result of behavior that improves with development). Other researchers have reported temporal and spatial associations between striped bass and white perch larvae and their zooplankton prey. For example, peak abundances of striped bass larvae were associated with areas of greatest zooplankton abundance in the Potomac River (Setzler-Hamilton et al. 1981). In addition, years when prey concentrations were high corresponded to years of high larval striped bass abundance and juvenile recruitment in the upper Chesapeake Bay (Rutherford et al. 1997). In the Hudson River, white perch larval growth rates were positively correlated with zooplankton density, and the largest fraction of juvenile striped bass began feeding as larvae during the time period when Bosmina longirostris concentrations peaked (Limburg et al. 1999).

Differences in the patterns of distribution between striped bass and white perch post-yolk-sac larvae may be related to prey preference or to preferred salinity/ temperature zones. Although high concentrations of both Eurytemora affinis and Bosmina longirostris copepods were found within the ETM region, their spatial distributions differed: most $E$. affinis were in salinities $>1$ psu while most $B$. longirostris were in salinities $<1$ psu. B. longirostris concentrations explained more of the variability in concentrations of feeding striped bass larvae than did E. affinis in multiple-regression models, while the opposite was found for white perch post-yolk-sac larvae. Possibly, striped bass larvae may have preferred B. longirostris over E. affinis and aggregated where $B$. longirostris concentrations were high. Alternatively, striped bass may have preferred (or survived better in) lower salinity or higher temperature waters where $B$. longirostris tended to be more prevalent than E. affinis.

Between years, changes in freshwater flow influenced the physical characteristics of the ETM region and the distribution of larval fishes and their potential prey in the upper Chesapeake Bay: peak concentrations of larval fishes and potential prey shifted upestuary in 1999, coinciding with the up-estuary shift in salt front location. In contrast to 1998, fewer white perch post-yolk-sac larvae, Eurytemora affinis and Bosmina longirostris were found within the ETM region in 1999 (Table 1), suggesting that there was less overlap between the planktonic community and the ETM region where most organic matter accumulated during the low-flow year. This mismatch could have reduced zooplankton production potential, resulting in poorer growth conditions for larval fishes. Although mean abundances of $E$. affinis were not significantly different between 1998 and 1999, zooplankton production could have differed between years even though standing stock abundances were similar. For example, high prey production coupled with high larval fish grazing rates during a high-flow year such as 1998 could have resulted in similar prey abundances between high- and low-flow years, but higher larval fish and prey production during the high-flow year.

Several lines of evidence suggest that freshwater flow may control inter-annual differences in larval survival and recruitment potential by influencing the physical and biological characteristics of the ETM region: (1) the difference in physical conditions within the ETM between years driven by variations in freshwater flow, (2) the reduced coupling between fish larvae, their prey and the ETM region in low-flow compared to high-flow conditions, (3) the reduced abundance of striped bass and white perch post-yolksac larvae in 1999 compared to 1998, (4) the positive correlation between river flow and YOY abundance (North \& Houde 2001), and (5) the improvements in spawner-recruitment model fit with incorporation of freshwater flow. Other researchers have found positive relationships between inter-annual freshwater flow and striped bass larval abundances, survival, and juvenile recruitment (Turner \& Chadwick 1972, Kernehan et al. 1981, Rulifson \& Manooch 1990, McGovern \& Olney 1996, Secor et al. 1996, Kimmerer et al. 2001). Variability in freshwater flow may influence the retention and survival of early-life stages within the ETM via flow-induced changes in convergence zone strength, by affecting overlap of preferred larval salinity/temperature zones with the area of highest prey production and greatest predation refuge in the ETM (North \& Houde 2001), and by controlling productivity in the upper estuary through delivery of organic material to the detritus-based food web (Turner \& Chadwick 1972, Boynton et al. 1976). Framed in the classic paradigms of fisheries science, changes in freshwater flow may influence striped bass and white perch recruitment success by controlling (1) earlystage retention within the ETM nursery area (Iles \& Sinclair 1982), (2) the timing and extent of prey production within the ETM region (Hjort 1914, Cushing 1975), (3) the spatial co-occurrence of larvae and visual predators within the high turbidity refuge (Bailey \& Houde 1989), and (4) the resulting subtle changes in growth and mortality rates (Houde 1989).

Improvements in spawner-recruitment models by incorporating spring freshwater discharge were notable: models with discharge explained considerably more of the variability in recruitment than did spawner abundance alone. It is uncertain if freshwater flow is an important factor controlling recruitment levels of striped bass in all Chesapeake tributaries but, since $>50 \%$ of 
spawning potential occurs in the upper Bay region (Hornick et al. 1999: their Table 7, p. 59), the effect of freshwater flow on recruitment could be substantial in the Bay. Incorporating environmental effects into other stock-recruitment models has successfully reduced variability in stock-recruitment relationships. For example, Crecco \& Savoy (1984) and Crecco et al. (1986) demonstrated that including freshwater discharge into a Ricker stock-recruitment model for American shad Alosa sapidissima in the Connecticut River substantially improved model fit. Incorporating parameters for river flow and temperature in Ricker stock-recruitment models for Pacific herring Clupea harengus pallasi also reduced variance in the model (Stocker et al. 1985).

A drawback associated with incorporating environmental factors into stock-recruitment relationships is the potential for spurious correlations (Sissenwine 1984, Boicourt 1988, Hilborn \& Walters 1992). Although correlative evidence certainly links freshwater flow to striped bass and white perch YOY recruitment (Wood 2000, North \& Houde 2001), results of the survey data and analysis presented here lend credence to a causative component in the relationship because specific mechanisms were identified that may link interannual fluctuations in freshwater flow to recruitment variability via processes operating at space and time scales relevant to larval survival in the ETM region of upper Chesapeake Bay.

Understanding environmental stochasticity is necessary to fully characterize the dynamics of teleost fish populations (Fogarty 1993b). Our results may benefit management of anadromous fishes in Chesapeake Bay by helping to partition the variance in the stockrecruitment relationship and thereby provide a better understanding of population responses to different levels of fishing mortality. Although co-varying environmental and biological signals makes the modeling endeavor challenging (Werner et al. 1997, Francis et al. 1998), the interrelationship between physical and biological factors is useful for modeling recruitment variability in Chesapeake Bay, because freshwater flow provides a strong environmental signal (Fogarty 1993a) that directly controls the physical characteristics of the ETM region. The results presented here demonstrate coupling between physical conditions, prey concentrations, and larval fish distributions in the ETM nursery area under different freshwater-flow conditions. Environmental variables such as freshwater flow can be integrative factors, incorporating a suite of effects that together determine larval survival and recruitment. Provided that the mechanisms behind the relationships are adequately understood, such integrative factors may be simple yet powerful tools that can be used to reduce variability in stock-recruitment models.
Potential long-term changes in freshwater flow related to global climate change and anthropogenic modifications of the estuary could have significant implications for striped bass and white perch recruitments. Wood (2000) demonstrated that the dominance of an Ohio Valley high-pressure system (associated with cooler and wetter springtime conditions) was correlated with high striped bass and white perch recruitments in Chesapeake Bay. Our results support Wood's analyses and identify potential mechanisms that link recruitment variability to climate-scale forcing via changes in freshwater flow. Although uncertainties in global climate-change models preclude accurate predictions of changes in stream flow in the Mid-Atlantic region (Wood et al. 2002), our research implies that long-term changes in flow due to climate change could influence larval fish survival and recruitment. Anthropogenic modifications to upper estuaries (e.g. dams, tide gates, impervious surfaces, dredged shipping channels, canals and dredge-disposal structures) also influence flow regimes. Such changes could affect circulation patterns or productivity in the ETM region and thereby influence larval fish survival and recruitment.

Acknowledgements. We appreciate the guidance of W. Boicourt, L. Sanford, and S. Suttles on ETM physics, M. Roman on zooplankton, E. Russek-Cohen on statistics, and M. Fogarty on stock-recruitment modeling. S. Jones, J. Boynton, L. Beaven, L. Pignolet, and M. Rhodes provided much appreciated assistance with sample processing. We are grateful for the capable field support provided by the captain, crew, and scientists on board the RV 'Orion'. We thank L. Waller, E. Durrell, and E. Zlokovitz of the Maryland Department of Natural Resources for supplying adult and juvenile fish survey data. This research was supported by the National Science Foundation Biological Oceanography Program (Grants No. NSF OCE-9521512 and OCE-0002543) and the EPA Science-ToAchieve-Results Fellowship Program (Fellowship No. U915366). This is contribution No. 3682 of the University of Maryland Center for Environmental Science, Chesapeake Biological Laboratory.

\section{LITERATURE CITED}

Abrams P (1980) Some comments on measuring niche overlap. Ecology 61:44-49

Albrecht AB (1964) Some observations on factors associated with survival of striped bass eggs and larvae. Calif Fish Game 50:100-113

Albrecht M, Gotelli NJ (2001) Spatial and temporal niche partitioning in grassland ants. Oecologia 126:134-141

Bailey KM, Houde ED (1989) Predation on eggs and larvae of marine fishes and the recruitment problem. Adv Mar Biol 25:1-67

Beaven M, Mihursky J (1980) Food and feeding habits of larval striped bass: an analysis of larval striped bass stomachs from 1976 Potomac Estuary collections. Final Report to Maryland Power Plant Siting Program. University of Maryland Center for Environmental Science, Solomons, MD (Ref No [UMCES]CBL 79-45) 
Boicourt WC (1988) Recruitment dependence on planktonic transport in coastal waters. In: Rothschild BJ (ed) Toward a theory on biological-physical interactions in the world ocean. Kluwer Academic Publishers, Dordrecht, p 183-202

Boynton WR, Setzler EM, Wood KV, Zion HH, Homer M, Mihursky JA (1976) Potomac River Fisheries Program, ichthyoplankton and juvenile investigations. Final report to Maryland Department of Natural Resources. University of Maryland Center for Environmental Science, Solomons, MD (Ref No [UMCES]CBL 77-169)

Boynton WR, Boicourt W, Brant S, Hagy J and 11 others (1997) Interactions between physics and biology in the estuarine turbidity maximum (ETM) of Chesapeake Bay, USA. ICES Annual Science Conference, Baltimore Int Counc Explor Sea Comm Meet 1997/S:11

Burnham KP, Anderson DR (1998) Model selection and inference: a practical information-theoretic approach. Springer-Verlag, New York, NY

Castel J, Veiga J (1990) Distribution and retention of the copepod Eurytemora affinis hirundoides in a turbid estuary. Mar Biol 107:119-128

Chesney EJ Jr (1989) Estimating the food requirements of striped bass larvae Morone saxatilis: effects of light, turbidity and turbulence. Mar Ecol Prog Ser 53:191-200

Chick JH, Van Den Avyle MJ (1999) Effects of zooplankton spatial variation on growth of larval striped bass: an experimental approach. Trans Am Fish Soc 128:339-351

Crecco VA, Savoy TF (1984) Effects of fluctuation in hydrographic conditions on year-class strength of American shad (Alosa sapidissima) in the Connecticut River. Can J Fish Aquat Sci 41:1216-1223

Crecco V, Savoy T, Whitworth W (1986) Effects of densitydependent and climactic factors on American shad, Alosa sapidissima, recruitment: a predictive approach. Can J Fish Aquat Sci 43:457-463

Crowder LB (1990) Community ecology. In: Schreck CB, Moyle PB (eds) Methods for fish biology. American Fisheries Society, Bethesda, MD, p 609-634

Cushing DH (1975) Marine ecology and fisheries. Cambridge University Press, Cambridge

Dauvin JC, Dodson JJ (1990) Relationship between feeding incidence and vertical and longitudinal distribution of rainbow smelt larvae (Osmerus mordax) in a turbid wellmixed estuary. Mar Ecol Prog Ser 60:1-12

Dew CB, Hecht JH (1994) Hatching, estuarine transport, and distribution of larval and early juvenile Atlantic tomcod, Microgadus tomcod, in the Hudson River. Estuaries 17: $472-488$

Dodson JJ, Dauvin JC, Ingram RG, and d'Anglejan B (1989) Abundance of larval rainbow smelt (Osmerus mordax) in relation to the maximum turbidity zone and associated macroplanktonic fauna of the middle St. Lawrence estuary. Estuaries 12:66-81

Doroshev SI (1970) Biological features of the eggs, larvae, and young of the striped bass (Roccus saxatilis (Walbaum)) in connection with the problem of its acclimatization in the USSR. J Ichthyol 10:235-248

Dovel WL (1971) Fish eggs and larvae of the upper Chesapeake Bay. NRI Special Report No. 4. University of Maryland Center for Environmental Science, Solomons, MD (Ref No [UMCES]CBL 71-88)

Draper NR, Smith H (1981) Applied regression analysis. John Wiley, New York

Fogarty MJ (1993a) Recruitment in randomly varying environments. ICES J Mar Sci 50:247-260

Fogarty MJ (1993b) Recruitment distributions revisited. Can J Fish Aquat Sci 50:2723-2728
Francis RC, Hare SR, Hollowed AB, Wooster WS (1998) Effects of interdecadal climate variability on the oceanic ecosystems in the NE Pacific. Fish Oceanogr 7:1-21

Goodyear CP (1985) Relationship between reported commercial landings and abundance of striped bass in Chesapeake Bay, Maryland. Trans Am Fish Soc 114:92-96

Hilborn R, Walters C (1992) Quantitative fisheries stock assessment: choice, dynamics and uncertainly. Chapman \& Hall, New York

Hirai N (2002) Development of freshwater adaptability in temperate bass during the early life history. $\mathrm{PhD}$ thesis, Kyoto University, Kyoto

Hjort J (1914) Fluctuations in the great fisheries of northern Europe viewed in the light of biological research. Rapp P-V Réun Cons Perm Int Explor Mer 20:1-228

Hornick HT, Waller LM, Warner LD, Goshorn CJ, Rodgers BA, Durell EQ, Shumate CM, Shoemaker HN (1999) Investigation of striped bass in Chesapeake Bay. Maryland Department of Natural Resources Performance Report to United States Department of the Interior Fish and Wildlife Service, project F-42-R-12. MD Fisheries Service, Annapolis, MD

Houde ED (1989) Subtleties and episodes in the early life of fishes. J Fish Biol(Suppl A)35:28-38

Iles TD, Sinclair M (1982) Atlantic herring: stock discreteness and abundance. Science 215:267-633

Jassby AD, Kimmerer WJ, Monismith SG, Armor C, Cloern JE, Powell TM, Schubel JR, Vendlinski TJ (1995) Isohaline position as a habitat indicator for estuarine populations. Ecol Appl 5:272-289

Kernehan RJ, Headrick MR, Smith RE (1981) Early life history of striped bass in the Chesapeake and Delaware Canal and vicinity. Trans Am Fish Soc 110:137-150

Kimmerer WJ, Burau JR, Bennett WA (1998) Tidally oriented vertical migration and position maintenance of zooplankton in a temperate estuary. Limnol Oceanogr 43(7):1697-1709

Kimmerer WJ, Cowan JH Jr, Miller LW, Rose KE (2001) Analysis of an estuarine striped bass population: effects of environmental conditions during early life. Estuaries 24: $557-575$

Limburg KE, Pace ML, Fischer D (1997) Consumption, selectivity, and use of zooplankton by larval striped bass and white perch in a seasonally pulsed estuary. Trans Am Fish Soc 126:607-621

Limburg KE, Pace ML, Arend KK (1999) Growth, mortality, and recruitment of larval Morone spp. in relation to food availability and temperature in the Hudson River. Fish Bull (Wash DC) 97:80-91

Linton LR, Davies RW, Wrona FJ (1981) Resource utilization indices: an assessment. J Anim Ecol 50:283-292

Mansueti RJ (1958) Eggs, larvae and young of the striped bass, Roccus saxatilis. Maryland Department of Research and Education, Contribution no. 112. University of Maryland Center for Environmental Science, Chesapeake Biological Laboratory, Solomons, MD

Mansueti RJ (1961) Movements, reproduction, and mortality of the white perch, Roccus americanus, in the Patuxent Estuary, Maryland. Chesapeake Sci 2:142-205

Mansueti RJ (1964) Eggs, larvae, and young of the white perch, Roccus americanus, with comments on its ecology in the estuary. Chesapeake Sci 5:3-45

Massmann WH (1963) The 'critical zone' in estuaries. Bull Sport Fish Inst 141:1-2

McGovern JC, Olney JE (1996) Factors affecting survival of early life stages and subsequent recruitment of striped bass on the Pamunkey River, Virginia. Can J Fish Aquat Sci 53:1713-1726 
North EW (2001) Transport and retention of fish early-life stages in Chesapeake Bay: mechanisms and implications for recruitment. PhD thesis, University of Maryland, College Park, MD

North EW, Houde ED (2001) Retention of white perch and striped bass larvae: biological-physical interactions in Chesapeake Bay estuarine turbidity maximum. Estuaries 24:756-769

Ricker WE (1975) Computation and interpretation of biological statistics of fish populations. Bull Fish Board Can 191:1-382

Robichaud-LeBlanc KA, Courtenay SC, Locke A (1996) Spawning and early life history of a northern population of striped bass (Morone saxatilis) in the Miramichi River estuary, Gulf of St. Lawrence. Can J Zool 74:1645-1655

Roman MR, Holliday DV, Sanford LP (2001) Temporal and spatial patterns of zooplankton in the Chesapeake Bay turbidity maximum. Mar Ecol Prog Ser 213:215-227

Rothschild BJ, Osborn TR (1988) Small-scale turbulence and plankton contact rates. J Plankton Res 10:465-474

Rulifson RA, Manooch CS III (1990) Recruitment of juvenile striped bass in the Roanoke River, North Carolina, as related to reservoir discharge. N Am J Fish Manag 10:397-407

Rulifson RA, Tull KA (1999) Striped bass spawning in a tidal bore river: the Shubenacadie estuary, Atlantic Canada. Trans Am Fish Soc 128:613-624

Rutherford ES, Houde ED, Nyman RM (1997) Relationship of larval-stage growth and mortality to recruitment of striped bass, Morone saxatilis, in Chesapeake Bay. Estuaries 20: $174-198$

Sanford LP, Suttles SE, Halka JP (2001) Reconsidering the physics of the Chesapeake Bay Estuarine turbidity maximum. Estuaries 24:655-669

Schoener TW (1970) Nonsynchronous spatial overlap of lizards in patchy habitats. Ecology 51:408-418

Schubel JR (1968) Turbidity maximum of the northern Chesapeake Bay. Science 161:1013-1015

Schubel JR, Pritchard DW (1986) Responses of upper Chesapeake Bay to variations in discharge of the Susquehanna River. Estuaries 9:236-249

Secor DH, Houde ED (1995) Temperature effects on the timing of striped bass egg production, larval viability, and recruitment potential in the Patuxent River (Chesapeake Bay). Estuaries 18:527-544

Secor DH, Houde ED, Monteleone DM (1995) A mark-release experiment on larval striped bass Morone saxatilis in a Chesapeake Bay tributary. ICES J Mar Sci 52:87-101

Secor DH, Houde ED, Kellogg LL (1996) Re-evaluation of the acidification hypothesis. In: Houde ED, Secor DH (eds) Episodic water quality events and striped bass recruitment: larval mark-recapture experiments in the Nanticoke River. Final Report to Maryland Department of Natural Resources. University of Maryland Center for Environmental Science, Solomons, MD, p 231-239, (Ref No [UMCES]CBL 96-083)

Setzler-Hamilton EM (1991) White perch, Morone americana. In: Funderburk SL, Jordan SJ, Mihursky JA, Riley D (eds) Habitat requirements for Chesapeake Bay living resources. Chesapeake Bay Program, Annapolis, MD, p 12.1-12.20

Setzler-Hamilton EM, Hall L Jr (1991) Striped bass, Morone saxatilis. In: Funderburk SL, Jordan SJ, Mihursky JA,

Editorial responsibility: Otto Kinne (Editor),

Oldendorf/Luhe, Germany
Riley D (eds) Habitat requirements for Chesapeake Bay living resources. Chesapeake Bay Program, Annapolis, $\mathrm{MD}, \mathrm{p}$ 13.1-13.31

Setzler-Hamilton EM, Boynton WR, Mihursky JA, Polgar TT, Wood KV (1981) Spatial and temporal distribution of striped bass eggs, larvae, and juveniles in the Potomac estuary. Trans Am Fish Soc 110:121-136

Setzler-Hamilton EM, Jones PW, Drewry GE, Martin FD, Ripple KL, Beaven M, Mihursky JA (1982) A comparison of larval feeding habits among striped bass, white perch and Clupeidae in the Potomac estuary. Final Report to Maryland Department of Natural Resources, University of Maryland Center for Environmental Science, Solomons, MD (Ref No [UMCES]CBL 81-87)

Setzler-Hamilton EM, Wright DA, Martin FD, Millsaps CV, Whitlow SI (1987) Analysis of nutritional condition and its use in predicting striped bass recruitment: field studies. Am Fish Soc Symp 2:115-128

Simenstad CA, Morgan CA, Cordell JR, Baross JA (1994) Flux, passive retention, and active residence of zooplankton in Columbia River estuarine turbidity maxima. In: Dyer KR, Orth RJ (eds) Changes in fluxes in estuaries: implications from science to management. Olsen \& Olsen, Fredensborg, p 473-482

Sirois P, Dodson JJ (2000) Influence of turbidity, food density and parasites on the ingestion and growth of larval rainbow smelt Osmerus mordax in an estuarine turbidity maximum. Mar Ecol Prog Ser 193:167-179

Sissenwine MP (1984) Why do fish populations vary? In: May RE (ed) Exploitation of marine communities. SpringerVerlag, Berlin, p 59-94

Stocker M, Haist V, Fournier D (1985) Environmental variation and recruitment of Pacific herring (Clupea harengus pallasi) in the Strait of Georgia. Can J Fish Aquat Sci 42: $174-180$

Strathmann RR (1982) Selection for retention or export of larvae in estuaries. In: Kennedy VS (ed) Estuarine comparisons. Academic Press, New York, p 521-536

Turner JL, Chadwick HK (1972) Distribution and abundance of young-of-the-year striped bass, Morone saxatilis, in relation to river flow in the Sacramento-San Joaquin estuary. Trans Am Fish Soc 3:442-452

Waldman JR, Young JR, Lindsay BP, Schmidt RE, Andreyko H (1999) A comparison of alternative approaches to discriminate larvae of striped bass and white perch. North Am J Fish Manage 19:470-481

Werner FE, Quinlan JA, Blanton BO, Luettich RA Jr (1997) The role of hydrodynamics in explaining variability in fish populations. J Sea Res 37:195-212

Winger PV, Lasier PJ (1994) Effects of salinity on striped bass eggs and larvae from the Savannah River, Georgia. Trans Am Fish Soc 123:904-912

Winemiller KO, Pianka RR (1990) Organization in natural assemblages of desert lizards and tropical fishes. Ecol Monogr 60(1):27-55

Wood RJ (2000) Synoptic scale climate forcing of multispecies fish recruitment patterns in Chesapeake Bay. $\mathrm{PhD}$ thesis, The College of William and Mary, Virginia Institute of Marine Science, Gloucester Point, VA

Wood RJ, Boesch DF, Kennedy VS (2002) Future consequences of climate change for the Chesapeake Bay ecosystem and its fisheries. Am Fish Soc Symp 32:171-184

Submitted: July 15, 2002; Accepted: March 11, 2003

Proofs received from author(s): September 2, 2003 